\title{
Yerel Yönetimlerin Tarihi Çevredeki İhya Politikalarının Yaşam Kalitesine Etkisi: Gaziantep Şehreküstü Bölgesi
}

\author{
Gamze Özmertyurt ${ }^{1}$ \\ ORCID: 0000-0002-0813-5503
}

*

\author{
İclal Sena Uncuoğlu ${ }^{2}$ \\ ORCID: 0000-0003-2510-1070
}

Öz

Yerel yönetimlerin, özellikle kentsel sit alanları içerisinde kalan ve kentin sosyal, kültürel, ekonomik canllı̆̆̆mı besleyen noktalardaki projeleri son dönemde hız kazanmıştır. Bu çalışmada yerel yönetimlerin tarihi çeorede uygulamaya koyduklar kentsel ihya projelerinin kentsel yaşam kalitesinin artmasında nasıl bir etkiye sahip olduğu ölçülmeye çalışılmıştır. Yapılan çalı̧̧manın örneklem alanı; Gaziantep kentinin kentsel sit alan sinırlar içerisinde bulunan Şehreküstü Bölgesi'ndeki Şehitler Caddesi aksı olarak belirlenmiştir. Çalı̧̧manın amacı, bu aks üzerindeki kültür varliklarınin korunmast ve ihya edilerek topluma kazandirlması amaciyla yap-lan çalışmaların değerlendirilmesi ve yerel politikaların bu bağlamda bölgeye sunduğu olanakların yaşam kalitesi parametreleri geliştirilerek ölçülmesinin sağlanmasıdır. Çalı̧manın metodolojisi, öncelikle ölçümlerin yapılması amacıyla kapsamlı akademik literatür taraması yapılması ve bölgeye özgü oluşturulan parametrelerin restorasyon geçirip yeniden işlevlendirilmiş kültürr varlıkları odak alınarak etki değerlendirilmesi yapılmasıdır. Cadde üzerindeki 16 adet tescilli yapının da içerisinde bulunduğu ticaret aksı olarak belirlenen alandaki sokak să̆liklaştırma projeleri, kamusal tesislerin dönüşümleri sürdürülebilirliği sağlama noktasında başarll olmakla birlikte kültür politikalarının tek başına değerlendirilmesi günümüzde uygulamada yeterli görülmemektedir. Sonuç olarak çalı̧̧manın yerel politikalar bağlamında tarihi çevrede yapılacak ihya projelerinin alana özgü değerlendirmesi yapılmıştır. Aynı zamanda bu çalışma, bölgede yapılacak sonraki projelerin kentsel yaşam kalitesine etkisi göz önüne alınarak önceliklendirilmesinde faydalı bir altlk olacaktır.

Anahtar Kelimeler: Gaziantep, ihya politikaları, tarihi çeore, yaşam kalitesi

\footnotetext{
${ }^{1}$ Arş. Gör, Yıldız Teknik Üniversitesi, E-mail: gamze_ozmertyurt@hotmail.com

${ }^{2}$ Gaziantep Büyükşehir Belediyesi, E-mail: iclalsenauncuoglu@gmail.com

idealkent @ C Kent Araştırmaları Dergisi (Journal of Urban Studies)

http://idealkentdergisi.com
}

Geliş Tarihi Received Date: 30.10.2020 Kabul Tarihi Accepted Date: 19.04.2021 


\title{
The Effect Of Local Governments' Recovering Policies in Historical Landscape On Quality Of Life: Gaziantep Şehreküstü District
}

\author{
Gamze Özmertyurt ${ }^{3}$ \\ ORCID: 0000-0002-0813-5503
}

*

\author{
İclal Sena Uncuoğlu 4 \\ ORCID: 0000-0003-2510-1070
}

\begin{abstract}
Projects of local governments, especially in the points of urban protected areas and feed the social, cultural and economic life of the city, have increased recently. In this study, the effect of urban regeneration projects implemented by local governments in the historical environment on the increase of the quality of urban life was measured. The model area of the study has determined as Şehitler Street Şehreküstü Neighborhood in Gaziantep Urban Protect Area. The study's aim is to evaluate the conservation activities on cultural assests of local administrations and to measure the opportunities offered by local policies to the region by improving the quality of life parameters. The study's methodology is to conduct a comprehensive literature review for measurements and to evaluate the impact of the region-specific parameters. Although the restoration of 16 historical buildings, including street transformations, is successful, today it is not sufficient for the evaluation of cultural policies. Consequently, field-specific evaluation of revival projects in the historical environment in the context of local policies has been made. Additionally, this study will be an useful base for prioritizing the next projects to be carried out in the region, considering their impact on the quality of urban life.
\end{abstract}

Keywords: quality of life, Gaziantep, historic landscape, recovering policies.

\footnotetext{
${ }^{3}$ Arş. Gör, Yıldız Teknik Üniversitesi, E-mail: gamze_ozmertyurt@hotmail.com

${ }^{4}$ Gaziantep Büyükşehir Belediyesi, E-mail: iclalsenauncuoglu@gmail.com

idealkent @ C Kent Araştırmaları Dergisi (Journal of Urban Studies) 


\section{Giriş}

Günümüzde kentlerde yerel yönetimlerin kentsel refah düzeyini artırmak ve kentin sürdürülebilir olmasını sağlamak için uyguladıkları plan ve projeler, özellikle tarihi çevrede çok farklı boyutta karar verilmesi gereken değişkenleri içermektedir. Bu değişkenler kentin tarihi, kültürel, sosyal, ekonomik, çevresel verilerini içermekte ve koruma bağlamında incelenmelidir. Özellikle kültür etkeni yerel yönetimlerin politikalarında bu bölgelere özgü karar verici işlevi ağırlıklı olarak üstlenmektedir.

Kentin kültür boyutunda incelenmesiyle kültür politikaları ortaya çıkmıştır. Evrensel ölçekte kültürün yönetim birimlerinin alanına girdiği üç unsur vardır. Tekeli (2011)'ye göre bunlar kültür endüstrisi, güzel sanatlar ve koruma alanlarıdır. Kültür politikaları kapsamında incelenen koruma alanlarına verilen önemin ivmesindeki artışı 2. Dünya Savaşı sonrası gerçekleşen yıkımlar ve sanayi devrimiyle gerçekleşen Fransız İhtilali etkilemiştir. Kente yönelik belirlenen yeni yaklaşımlarda koruma, yok olan, değersizleştirmeye çalışılan kültür kavramının canlandırılması ve yere özgü olarak güçlü bağlara sahip olmasını amaçlayarak gerçekleştirilmiştir. Böylece kültürel miras, somut ve somut olmayan miras kavramlarını besleyen yeni kavramlarla bütünleşmiştir. Bunlar; mekanın dili, mekanın ruhu, kültürel peyzaj, kültürel planlama, kimlik, karakter ve kentsel kalite gibi kavramlardır (Can, 2014, s.57). Kentsel kalitenin, miras kavramı düşünülerek ele alınması önemlidir. Yerel kimliğin ve bunun ürünü olan miras değerlerinin gelişen ve büyüyen kentlerde, özellikle tarihi çevrelerde geri plana bırakılması riski bulunmaktadır. Yerel yönetimlerin koruma olgusuyla hareket etmesi o bölgeye hem kimliğin sürdürülebilir olması konusunda hem de eğitim, sosyal, ekonomik, sağlık gibi temel insani ihtiyaçların bir arada karşılanabilmesi için imkân sağlamaktadır.

Çalışmanın amacı, gelişen ve büyüyen dünyamızda kültürel mirasın sürdürülebilir gücü ön plana çıarılarak, günümüzün insani yaşam kalitesi beklentilerini karşılayabilecek fonksiyonların planlanmasında yerel yönetimlere yol gösterecek bir kılavuz oluşturmaktır. Her ülkenin hatta her bölgenin içinde bulunduğu coğrafi, fiziksel, ekonomik, ekolojik, sosyal v.b. farklılıklar göz önüne alınırsa ihtiyaç ve beklenti kavramının karşılığı için tek bir yol gösterici harita olması düşünülemez. Bu nedenle yapılan çalışmada da kapsam alanı daraltılarak Gaziantep kenti Şehreküstü bölgesi seçilmiştir. Tarihi geçmişi, kültürel birikimi, koruma bilinciyle faaliyet gösteren yerel yönetim kapasitesindeki verimlilik ve ayn zamanda kalkınmanın organik kent dokusu 
üzerindeki zorlayıcı gücü, coğrafi olarak göçmen nüfusu barındırma durumu gibi olgular bu bölge üzerinde çalışılmasını gerekli kılmıştır. Çalışmanın akış şeması: Giriş, literatür taraması, yöntem ve yöntemde kullanılan göstergelerin aşamaları, bulgular ve sonuç olarak 5 aşamada tamamlanacaktır (Şekil 1).

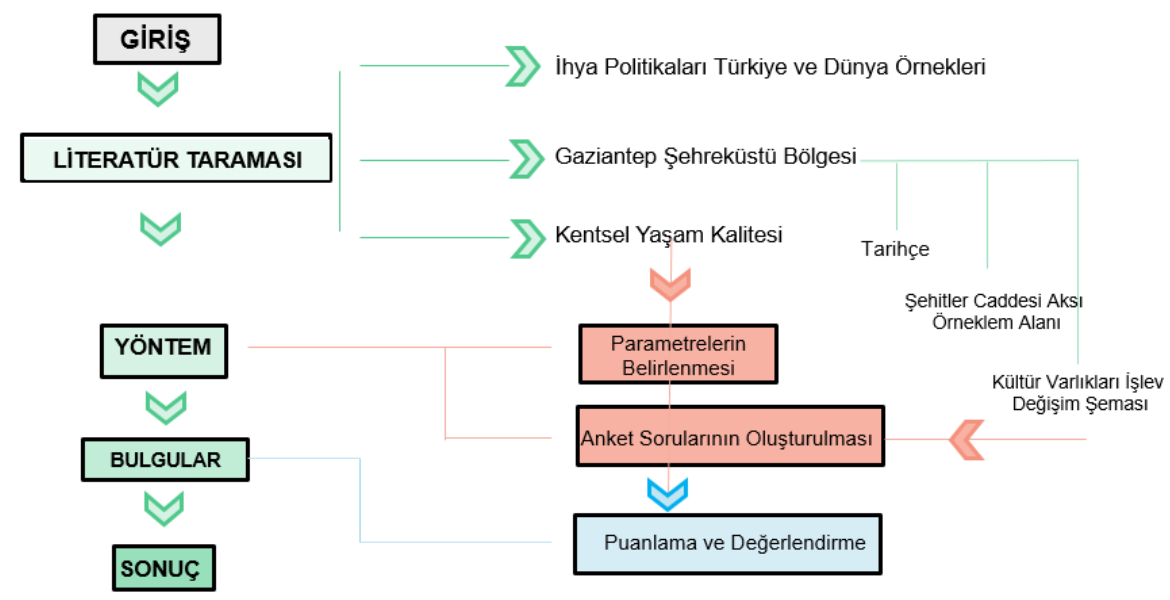

Şekil 1. Makalenin akış şeması.

\section{Kentsel Yaşam Kalitesi}

Kentsel yaşam kalitesi kavramını açmadan önce yaşam kalitesinin ne olduğu ifade edilmelidir. Yaşam kalitesi her disiplin içinde kendine yer edinebilen çok boyutlu bir kavramdır. Birçok araştırmacı yaşam kalitesinin ne olduğu üzerine görüş geliştirmiştir. Bunlardan kentsel yaşam kalitesi kavramını daha iyi açıklayabilmek adına Veenhoven (2000), dörtlü yaşam kalitesi kavramını ifade etmiştir. Buna göre refah ve mutluluğa karşılık gelen yaşam kalitesi;

-Yaşanabilir çevre

-Kişinin yaşam kabiliyeti

-Yaşamın yararı

-Yaşamın değerini bilme olarak açıklanmaktadır. Yaşam kalitesi kavramında nesnel ve öznel ölçütler yer almaktadır. Kültürden kültüre, bireyden bireye değişebilen durumların ölçülebilmesi adına nesnel ölçütlerin öznele indirgenmesi önemlidir (Türksever, 2001, s. 13).

Kentsel yaşam kalitesi kavramı ise yaşam kalitesinin kentsel ölçekte alg1lanmasıyla ilgilidir. Toplumsal, kültürel, siyasal ögeleri ve bunların süreçlerini de içine dahil eden bir kavramdır. Kent yaşamının sunduğu eğitim, sanat, siyasal, sosyal, ekonomik etkinliklere örgütsel ve bireysel olarak aktif şekilde 
faydalanabildiği durumları kapsamaktadır (Kabadayı, 2006, s.16). Kentsel yaşam kalitesinin iyi olma hali o bölgede yaşayan insanların memnuniyeti ve bölgeden dışarıya göçün az sayıda olduğu durumlarla da karşılanabilmektedir. Özellikle refah seviyesi yüksek, çevresel kalitesi iyi, sosyal ihtiyaçlara cevap verebilen bölgelerde insanların yerleşme eğilimi yüksektir. Altyapı, ulaşım, güvenlik hizmetlerinin de sağlanabilmesi kalitesel artışı etkileyecektir. Aksi durumlarda bireylerde yer değiştirme, bulundukları bölgeyi terk etme durumu ortaya çıkmaktadır. Bu da bölgeler arası dengesizlik ve göç sorununu oluşturmaktadır (Torlak ve Yavuzçehre, 2005, s.328). İnsanların yaşam kalitesi memnuniyeti genel yaşam kalitesinden farklı düzeyde ele alınmalıdır. Kentsel yaşam kalitesi yerel yönetimlerin planlamalarında toplumsal stratejilerin nasıl önceliklendirilmesi gerektiğini açıklayan bir olgudur (Donald, 2001, s.259).

Kentsel yaşam kalitesi kavramı dünya tarihinde ilk olarak İngiltere' de salgin hastalıklarla mücadelede oluşturulan 1832 tarihli kanunla yaşam kalitesini iyileştirme hedefiyle gündeme gelmeye başlamıştır. Sonraki dönemlerde kent estetiğini vurgulayan ve bununla bağlantılı pek çok akım ortaya atılmıştır (Şekil 2.).

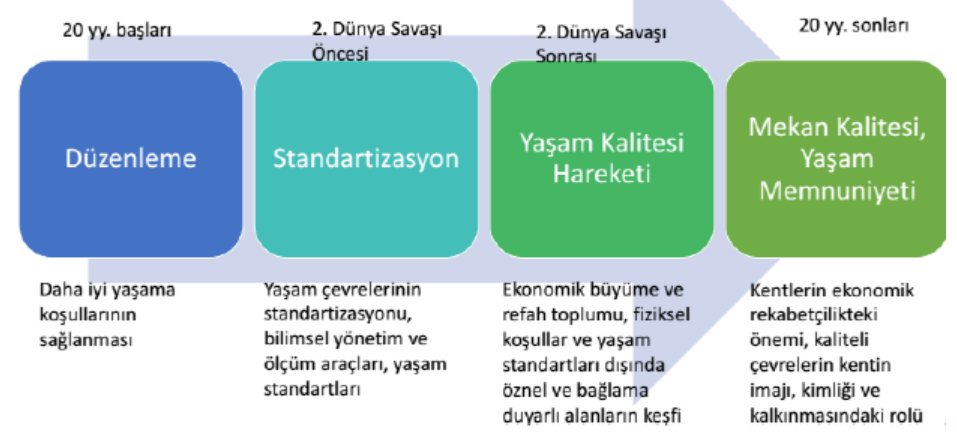

Şekil 2. Kentsel yaşam kalitesi dünyadaki gelişimi. Kentsel Yaşam Kalitesi Özel İhtisas Komisyonu Raporu, 2018, s.14 raporundan aynen alınmıştır.

1930'larda Atina Antlaşması ile şehircilik ilkeleri üzerinde durulmuştur. 1970'lerden sonra ise özellikle küresel ısınma, ozon tabakasının delinmesi, Çernobil gibi çevresel felaketler kentli hakları üzerinde daha fazla düşünülmesi gerektiğini gündeme getirmiştir. Refah seviyesini artırmak için yapılan kalkınma girişimlerinin sosyal ve ekolojik çevredeki etkisini en aza indirgemek amaçlanmıştır (Türkoğlu, 2020, s.118). Kentli hakları daha sonra birçok 
çerçevede ele alınmıştır. Bunlar; ilki 1972'de diğer ikisi 1992 ve 2012'de gerçekleşen Birleşmiş Milletler Dünya Sürdürülebilir Kalkınma Konferansı Zirve Deklarasyonu, Birleşmiş Milletler 'in 20 yılda bir gerçekleştirdiği ilki 1976'da gerçekleşen; Habitat I, Habitat II (1996), Habitat III (2016), 1994 Uluslararası Nüfus ve Kalkınma Konferansı, 2001 İstanbul +5 olmuştur (Torlak ve Yavuzçehre, 2006, s.188). Son dönemlerde kentsel yaşam kalitesi kavramına ilişkin vurgunun yapıldığı uluslararası metinler ise bunlara ek; Paris Anlaşması (2016), Engellilerin Haklarına İlişkin Sözleşme (2008), AB Sürdürülebilir Avrupa Kentleri için Leipzig Şartı (2007) olmuştur. Bunlardan Türkiye'de gerçekleşen Habitat II'de kentsel yaşam kalitesinin önemli bileşenlerinden olan yaşanabilirlik ilkesinin insan hakları temellendirilmesinde yer alması üzerine öneri getirilmiştir (Kentsel Yaşam Kalitesi Özel İhtisas Komisyonu Raporu, 2018, s.25). Habitat III sonrası gündeme taşınan temel kavramlar sürdürülebilirliğe ek kapsayıcılık (inclusivity) ve dayanıklılık (resilience) olmuştur. Diğer gündemlerden farklı olarak Habitat III te dikkat çeken nokta yerel yönetimlerin taraf devletlerin yanı sira karar almada ve bu platformda bulunmada yükselen talepleri olmuştur (Yıldırım, 2017). Kentsel yaşam kalitesi kavramı ve bunun iyileştirilmesi hedefine yönelik AB (Avrupa Birliği) birçok anlaşmaya imza atmıştır. Yaşam kalitesini artırma hedefi için ekonomik ve sosyal ilerleme, sağlam adımlarla ilerleme ve sürekliliğin sağlanabilmesi temel amaçlar olmuştur. Bunların gerçekleştirilmesinde yerel yönetimler ön plana çıkarılmıştır (Demirkaya, 2008, s.164). Kentsel yaşam kalitesi kavramıyla birlikte "Dirençli Kentler" başlığı da sorunu daha farklı açıdan ele alabilmektedir. Kentlerin sadece afetlere, ekolojik problemlere karşı değil aynı zamanda sosyal ve ekonomik değişimlere karşı da dirençliliğini artırmayı hedefleyen bir kent hareketi olarak günümüzde tartısılmaktadır (Bodur, 2018, s.1261). Kentlinin yaşam kalitesini artırma hedefiyle kenti dirençli hale getirme hareketinin benzer grafik eğrileriyle orantılı olarak değişim gösterdiği söylenebilir.

\section{Kentsel Yaşam Kalitesinin Ölçülmesi}

Yerel yönetimlerin sürdürülebilir kalkınmanın hayata geçirilmesinde öncü rol oynaması kentler için daha iyi bir yaşam kalitesini belirleyen kent planları oluşturulmaya başlanmıştır. Dolayısıyla yaşam kalitesinin ölçülmesi tek bir değişkene bağlı formülize edilebilir bir kavram olmaktan çok bölgeye özgü değişkenlere göre şekillenebilen ölçüm metotları geliştirilerek ölçülebilmektedir (Türkiye'nin Şehirleri Sürdürülebilirlik Araştırması, 2011, s. 7). Gü- 
nümüzde kentsel yaşam kalitesinin ölçülmesi konusunda çalışan araştırmacılar yaşam kalitesinin anlaşılması ve ölçülmesi; değişkenlerin, hangi parametrelerin kullanılacağı konusunda çalışmaktadır (Marans, 2007). Tekeli (2010)'ye göre yaşam kalitesi göstergeleri 2 boyutta ele alınabilir. Öznel ve nesnel ölçütler olarak ayrılabilen göstergeler de kümülatif ve bireysel olmaları dolayısıyla farklılaşabileceğinden 4 çeşit kalite göstergesi tanımlanabilir. Komünitenin refahı(welfare) ve üyelerin iyi olma (well-being) hali yaşam kalitesini tanımlamaktadır. Tekeli ayrıca bireysel düzeyde öznel ölçütler, bireysel düzeyde nesnel ölçütler, komünite düzeyinde algılama ölçütleri ve komünite düzeyde nesnel ölçütler olarak ölçütleri sınıflandırmıştır. Dünyada yaşam kalitesi ve sürdürülebilirlik için yaşanabilirlik, yaşam kalitesi gibi birçok endeks geliştirilmiştir. Bu endekslerin ölçülebilmesi için nesnel ölçütlerin tek başına var olması mümkün değildir. Nesnel verilerin yetersiz kaldığ 1 durumlarda öznel uzman görüşlerine yer vermek gerekir (Cooper ve Marans, 2000, s. 268). Bu bağlamda ulusal ve uluslararası düzeyde kurumlar tarafından yaşam kalitesinin çevre, engelliler, enerji gibi ilişkili alanlarda oluşturdukları standardizasyon süreçleri bulunmaktadır. Yaşam kalitesi başlı̆̆ında oluşturulan bir standart bulunmamaktadır. Uluslararası Standartlar Teşkilatı (ISO) daha çok iktisadi bir kavram olan "yaşam standardı" kavramını çevre başlığında inceleyerek bir standart oluşturmuştur. Kentsel yaşam kalitesi kavramı bu kavramdan farklı olarak değişkenlerden etkilenebilen daha soyut bir kavramdır (Kentsel Yaşam Kalitesi Özel İhtisas Komisyonu Raporu, 2018, s. 26). Kentte yaşayanların hizmetlere erişebilirliği ve kentli hakkı gibi nesnel ölçütlerle kentlilerin hizmetlere yönelik memnuniyet düzeyleri ve öznel değerlendirmeleri kentsel yaşam kalitesinin belirleyicisidir (İnan ve Sönmez, 2019, s.186).

\section{Ulusal Ölçekteki Uygulamalar}

Türkiye'de kentsel yaşam kalitesi ile ilgili çalışmalar yaklaşık otuz yıldır yer almaktadır. Bunda kentleşmenin geçirdiği hızlı dönüşümün etkisi büyük olmuştur. Gecekondu bölgelerinin yeni yapılaşmalarla sıkıştırılması, bu bölgelerde düşen yaşam kalitesi kentsel dönüşüm olgusunu gündeme getirmiştir. Kentsel yaşam kalitesinin ölçümü için nesnel ölçütlere başvurulmuştur. Bu kavrama yer verilmesine ilk kez Devlet Planlama Teşkilatı (DPT) tarafından hazırlanan kalkınma planlarına ilk kez 7. Beş Yıllık Kalkınma Planında (1996-2000) dâhil edilmiştir. Türkiye İstatistik Kurumu (TUİK) ise 2003'te başlayarak her yıl yaşam memnuniyeti araştırması yapmıştır (Bilgili, 2017, s. 86). UNDP (Birleşmiş Milletler Kalkınma Programı)'nın 1992'den 2008'e kadar 
süren ölçümleri Türkiye'nin İGE (İnsani Gelişme Endeksi) değerini diğer ülkeler ile karşılaştırılmış hem de ülke içinde insani gelişim düzeyleri ölçülmüştür. Türkiye Ekonomi ve Politika Araştırmaları Vakfı (TEPAV) tarafından 2008'te Bayındırlık ve İskân Bakanlığı (BIB) kentlerin teknik alt yapılarının ve ekonomi, kültürel, sosyal durumlarının belirlenmesine ilişkin çalışma yapmıştır. Ülke kapsamında 7 temel alan 23 alt alanda 156 gösterge oluşturulmuştur (Mazcıoğlu, 2018, s.18). Türkiye Bilimler Akademisi'nin ölçümlere yönelik nesnel önerileri mevcuttur. 2004 yılında "Komünite Düzeyinde Yaşam Kalitesinin Nesnel Değerlendirme Ölçütleri" çalışmasında kentsel yaşam kalitesi için ölçütler geliştirilmiştir. 2013 yılında ülke içindeki iller arasında benzer bir ölçüm yapılmıştır (Kentsel Yaşam Kalitesi Özel İhtisas Komisyonu Raporu, 2018, s.34). Yapılan çalışmalarda geliştirilen göstergeler genel olarak uluslararası standartlarda kullanılan ve önerilen göstergelere benzerdir. Sağllk, sanayi, eğitim, istihdam, çevresel sürdürülebilirlik, sosyal durum gibi göstergelere yer verilmiştir.

\section{Uluslararası Ölçekteki Uygulamalar}

$\mathrm{Bu}$ bölümde kentsel yaşam parametrelerinin belirlenmesi ve ölçülmesinde bazı uluslararası kuruluşların yaptığı güncel çalışmalardan bahsedilecektir. Bunlardan Birleşmiş Milletler (BM), sürdürülebilir kalkınma kavramını öne çıkaracak şekilde BM Sürdürülebilir Kalkınma Zirvesinde “2030 Sürdürülebilir Kalkınma Hedefleri” başlığında gelecek 15 yıllık kalkınma hedefleri sunmuştur. 17 adet hedef; yoksulluk, açlık, sağlık, eğitim, cinsiyet eşitliği, temiz su, temiz enerji, iş ve ekonomi, sanayi, eşitsizliklerin azaltılması, sürdürülebilir şehir yaşamı (11. Madde), sorumlu tüketim ve üretim, iklim planı, suda yaşam, karasal yaşam, barış ve adalet, hedefler için ortaklık başl1ğında ve bunların alt başlıklarında belirlenmiştir (T.C. Cumhurbaşkanlığ Strateji ve Bütçe Başkanlığı, 2019, s.4). İlk kez sürdürülebilir kalkınma kavramindan Brundlant Raporu'nda (1987) bahsedilmiştir. Ekonomik, sosyal ve çevresel boyutta ele alınan sürdürülebilir kalkınmada; kıt kaynakların kullanımı, bunların çevreye etkileri ve sosyo-kültürel sistemlerin sürekliliğinin sağlanması başlangıç hedefleri olmuştur (Şekil 3.) (Gürlük, 2010, s.86). Kentsel yaşam kalitesi için oluşturulacak parametrelerin belirlenmesinde bu hedefler ve 3 anahtar kavram altlık oluşturmaktadır. 


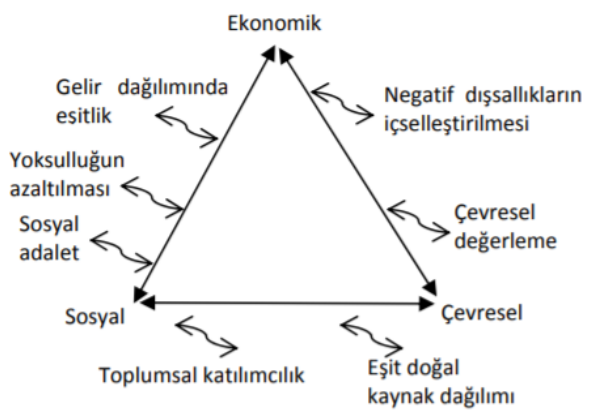

Şekil 3. Sürdürülebilir Kalkınmanın temel boyutu. “Sürdürülebilir kalkınma gelişmekte olan ülkelerde uygulanabilir mi?", Gürlük, 2010, s. 87 makalesinde yer alan Munasinghe (2001)'dan aktarilmıştır.

Uluslararası Standardizasyon Organizasyonu (ISO)'nun ilk kez 2014 y1lında kentsel yaşam kalitesi göstergeleri için belirlediği parametreler bulunmaktadır. Bu standardın içeriğinde, sürdürülebilir kalkınmanın 3 temel kavramın içeren kent göstergeleri mevcuttur. Büyüklüğüne, konumuna bakılmaksızın her türlü belediye, yerel yönetim yapısının kullanabileceği performans ölçümü yapıp, karşılaştırma yapılabilecek bir standarttır (ISO 37120, 2014). OECD(Ekonomik Kalkınma ve İşbirliği Örgütü), BM-Kentsel Göstergeler Programı ve AB-Kentsel Denetim Çalışması gibi uluslararası kurumlar da göstergeler belirleyerek kentsel kalitenin ölçümü konusunda parametreler belirtmiştir. Bunlardan OECD, Daha İyi Yaşam Endeksini (Better Life Index) hesaplamaktadır. Üye olunan ülkeler arasındaki kalkınma durumu incelenmektedir (İnan ve Sönmez, 2019, s.189). BM-Habitat'ın öncülüğünde 1993'te oluşturulmuştur. Kentsel gelişmişliğin sağlanabilmesi için veri araştırması yapmaktadır (United Nations [UN], 2004, s.3) . Kentsel yaşam kalitesinin ölçümü üzerine uluslararası kurumlar tarafından yapılan araştırmalar çok geniş ölçekte kentleri kapsarken, kendi içinde kentleri arasındaki rekabet ölçümleri ön plana çıkmıştır. Kentsel yaşam kalitesi, kültürden kültüre, ekonomik, sosyal beklenti durumlarının farklılıklarına göre daraltılması gereken bir olgudur. Bunları belirleyebilmek için ise insan odaklı, yerel toplum odaklı çalışmaların sayısı artırılmalıdır.

\section{Tarihi Çevredeki İhya Politikaları}

Tarihi çevreler, geçmiş ile bugün arasında bağlantı kuran, günümüzün sıradanlaşan birbirine benzer yapılar topluluğu halini alan kentlerin kimliği üzerinde önemli bir rol oynayan kültür varlıklarıdır (Çelik ve Yazgan 2009, s.1). 
Bu kültür varlıklarına; önceki nesillerden günümüze kaldığı ve gelecek nesillere miras kala 'kültürel miras' da denilmektedir. Bugünkü kültürel miras a cağı için anlayışının temeli UNESCO'nun 1972 yılında kabul ettiği Dünya Kültürel ve Doğal Mirasın Korunmasına Dair Sözleşme ile atılmıştır. UNESCO "Kültürel miras" kavramını tarihi ve yapılaşmış çevreyi oluşturan anıtlar, mimari değeri olan yapı grupları ve alanlar olarak tanımlanmaktadır (UNESCO [United Nations, Educational, Scientific and Cultural Organization], 1972). Kültürel miras olarak nitelendirilecek değerler yine UNESCO tarafından 1972 yılında kabul edilen Dünya Kültürel ve Doğal Mirasının Korunmasına Dair Sözleşme kapsamında tanımlanmıştır. Sözleşmeye göre uluslararası alanda kültürel miras; anitlar, yapı toplulukları ve sitler olmak üzere 3 ana başlık altında toplanmıştır. Anıtlar; tarih, sanat veya bilim açısından istisnaî evrensel değerdeki mimari eserler, şaheserler, arkeolojik nitelikte eleman veya yapılar, kitabeler, mağaralar ve eleman birleşimlerini kapsamaktadır. Yapı toplulukları; mimarileri, uyumlulukları veya arazi üzerindeki yerleri nedeniyle tarih, sanat veya bilim açısından istisnaî evrensel değere sahip ayrı veya birleşik yapı topluluklarından oluşan kültür varlıklarıdır. Sitler ise tarihsel, estetik, etnolojik veya antropolojik bakımlardan istisnaî evrensel değeri olan insan ürünü eserler veya doğa ve insanın ortak eserleri ve arkeolojik sitleri kapsayan alanlardır (UNESCO, 1989).

Somut ve somut olmayan kültürel mirasın sürdürülebilirliği kapsamında UNESCO'nun yapmış olduğu çalışmalar önemlidir. “Hızla küreselleşen dünyada kültürel miras eserleri, sadece bulundukları ülkelerin değil, dünyadaki tüm insanların değerleridir" bakış açısına sahip olan UNESCO, somut ve somut olmayan kültürel mirasın korunması amacıyla çeşitli çalışmalar sürdürmektedir (Gülhan, 2016, s.62).

İnsanın doğa ile etkileşimi sonucu oluşan kültürün somut ve somut olmayan ürünlerinin birikimi olan kültürel miras geçmişten günümüze daha fazla öğeyi ve konuyu içerecek şekilde bir gelişme sürecindedir. Bu gelişme sürecinin sonucu olarak kültürel mirasın korunması ve yönetimi de bu genişleyen kapsamla çok daha geniş bir içeriğe kavuşmuştur. Kültürel miras anlayışındaki değişimin ve genişleyen kapsamın en belirgin yansımaları kentlerde ortaya çıkmaktadır (Eryazıcıoğlu, 2018, s.1). Tarihi çevre kavramı içinde değerlendirilen kentler; kültürel mirasımızın önemli bir parçasıdır. Dolayısıyla kentler kültürel mirasın ve tarihi çevrenin en önemli çıkış noktasını oluşturmaktadır (Altunsoy, 2005, s.4). Kolayca tahrip olan, bozulan ve bir kez yok olduğunda, yerine yenisinin konması mümkün olmayan bir değerler bütünü 
olan tarihsel, doğal, kültürel değerlere sahip kentlerin korunmasına küreselleşen dünyada her geçen gün daha çok önem verilmektedir. Çünkü tarihi çevre, sadece bir mirasın gelecek nesillere aktarılması açısından değil, toplumdaki bireylerde tarihi bilincin ve yurttaşlık bilincinin uyandırılması konusunda da önem arz etmektedir (Bilenser, 2002, s.10).

Son yıllarda bu eşsiz tarihi çevrenin ve kentsel mirasımızın değeri tüm dünyada olduğu gibi ülkemizde de benimsenmiş, fakat bu mirasın korunması konusu ülkemizde ne yazık ki önemli bir sorun olmaya devam etmektedir. Çünkü bu eşsiz değerler, bu çok kıymetli miras doğal nedenlerle, değişen sosyal ve ekonomik şartlar nedeniyle yok olma tehdidi altındadır. Ülkemizde özellikle 1950'lerden sonra yaşanan hızlı kentleşme ve kentlere göçün kendini göstermeye başlaması ile, kentlerimizin büyük bir bölümü plansız şekilde gelişirken, tarihi kent dokularında da büyük ölçüde yıkım ve yeniden yapım süreci yaşanmış, bütün kentlerin görünümleri birbirinin ayn hale gelmiş, kendilerine has kimliklerini neredeyse kaybetmişlerdir (Varol, 2019, s.17). Bunun sonucu, kentlerimizde, nitelikli, kimlikli, belli bir dönemin mimari karakterini yansıtan değerli sivil mimari örneklerinden büyük çoğunluğu yıkılıp yok edilmiş, bunların yerine günümüzün sıradanlaşan birbirine benzer yapılar topluluğu halini alan kentler ortaya çıkmıştır (Beyhan ve Öçal, 2010).

Hızla artan nüfusun etkisiyle yaşanan hızlı kentleşme, iç ve dış göç, hızlı yapılaşma, yanlış kullanma ve modernleşmenin etkisiyle bugün yok olma tehdidi altınki tarihi alanların korunmaları, bakım ve onarımlarının yapılması gerekmektedir. Sürdürülebilirliğini sağlayarak ve yaşatarak gelecek nesillere ulaştırmamız gereken tarihi çevrenin korunması ve yaşatılması konusunda en önemli görev yerel yönetimler ve kültürel mirası koruma bilincine erişmiş kent halkının ortak sorumluluğudur. Gelecek kuşaklarında kültürel mirasımızdan yararlanması ve yerel halk arasında koruma bilincinin gelişmesi konularında yerel yönetimlerin tarihi çevre konusundaki koruma kültürü, koruma planları, ilkeleri ve yöntemleri çok önemlidir. Yerel yönetimler bu konuda kentliler ve sivil toplum kuruluşları ile el ele vererek, tarihin egemen olduğu kültürel sürekliliğin sağlandığı kentler yaratmalıdır.

Tarihi kent dokularının korunması ve sürdürülebilirliğinin sağlanması, tarihi yapıların değerlendirilmesi, doğru fonksiyonların verilmesi ve kullanılması ile mümkündür. Tarihi dokunun korunmasında öncelikle çağdaş gereksinimler göz önüne alınarak doğru fonksiyonlar verilmeli, daha sonra merkezi yönetim ve yerel yönetimler, tarihi kent dokusu içindeki yapıları gerekli şartları sağlayarak yeni kullanımlar için teşvik etmeli yani bu yapıları, 
bu eşsiz mimari eserleri yeni kullanımlara açılmalıdır (Yenişehirlioğlu, 2002, s.71). Ayrıca yerel yönetimler kültürel mirasın, tarihi dokunun korunması için halkın ilgilenmesini ve bilinçlenmesini sağlamak amacıyla eğitimler düzenlemeli kentin tarihi çevresinin düzenlenen bir program dahilinde gezdirerek bu eşsiz kültür miraslarını tanıtmaya çalışmalıdır (Ersezgin, 2002, s.65). Yerel yönetimler; tarihsel ve kültürel sürekliliğin sağlanması, tarihî çevrenin çağdaş yaşam koşulları doğrultusunda daha sağlıklı fakat kimliğini koruyarak canlandırılması, tarihî yapıların değerlendirilmesi ve geleneksel yerleşim modelini koruyarak tarihî çevreleri koruma ve yenileme konusunda çalışmalar yapmalıdır (Basmacı, 2017, s.80).

Kültürel sürekliliği sağlamak ve kent kimliklerini korumak için kültürel mirasımız olan tarihi kentsel doku korunarak yaşatılmalıdır.

\section{Gaziantep Kenti ve Şehreküstü Bölgesi}

Mezopotamya Bölgesi'nin Anadolu'ya açılan kapısı niteliğinde olan kent; tarih boyunca değişik uygarlıkların, kültürlerin ve inançların harmanlandığ bir çekim merkezi olmuş günümüzde de bu özelliklerin etkisiyle Güneydoğu Anadolu Bölgesi'nin en büyük kenti, en önemli kültür ve ticaret merkezidir. TÜİK (2019) verilerine göre kentsel nüfusu \%91,4, kırsal nüfusu ise $\% 8,6$ olan kentte tarım, hayvancılık, el sanatları, sanayi ve ticaret gelişmiştir.

Güneydoğu Anadolu Bölgesinin en büyük ve en gelişmiş kenti olan Gaziantep; tarihi ve kültürel zenginliği, jeopolitik konumu, demografik yapısı ve üretim alanlarındaki gelişen çizgisiyle bölgedeki en önemli merkez olmayı başarmıştır (Atasoy, 2018, s.21). Aynı zamanda tarihi yönünü besleyen geleneksel dokusuyla da literatürde adından söz ettirmektedir. 2015'te UNESCO Yaratıcı Şehirler Ağına gastronomi alanında katılmış, UNESCO Geçici Listesinde ise Kastel ve Livasları, Zeugma Antik Kenti ve Yesemek Açık Hava Müzesi ile tescilini uluslararası düzeye taşımıştır. Kent merkezinde tarihi dokunun devamlılığıyla birlikte gelişmeye ve yayılmaya devam eden geleneksel bölgeler başta Kale ve çevresi olmak üzere Şehreküstü Bölgesi, Türktepe, Bey Mahallesi olarak gösterilebilir. Çalışma alanı sınırlarının da içinde bulunduğu Şehreküstü Bölgesi, tarihi Suyabatmaz, Kepenek, Kozluca Mahallelerini de içine alan geniş bir alandır.

\section{Kentin Tarihçesi}

Gaziantep tarih öncesi çağlardan itibaren farklı uygarlıklara yerleşme sahası ve uğrak yeri olmuştur. Kent, jeopolitik konumunun verdiği üstünlükle 
tarih boyunca Anadolu'da kurulan ve Anadolu'ya egemen olan tüm devletler için önemli bir merkez olmuştur. Anadolu'nun ilk yerleşim yerlerinden biri olan Gaziantep kentinin tarihi ile ilgili yapılan araştırmalara ve yapılan kazılarda ele geçen buluntulara göre yöredeki ilk yerleşimlerin M.Ö. 10.000'lere dayandığı bilinmektedir. Bölgede yapılan kazılarda Kalkolitik, Tunç, Mitanni, Hitit, Asur, Pers, Roma, Bizans, Selçuklu, Osmanlı dönemlerine ait kalıntılarda bulunmuştur (Şahin, 2016, s.16). Gaziantep'in yerine geçtiği söylenen Dülük Köyü civarında yer alan Şarklı Mağara Paleolitik dönem insanlarının barındıkları yerdir (Kuban, 2001, s.121 ).

Gaziantep yöresi Geç Tunç Çağında (M.Ö. 1400-1200) Hitit Devleti'nin merkez kenti haline gelmiş ve Frigya Devleti'nin kurulması sonucu Gaziantep bağımsız Hitit Kent Devleti olmuştur (Egeplan, 2020, s.11). İlk çağlara ait kalıntıların bulunduğu Dülük (Doliche) ve Kale kentleşmenin ilk başladığı yerler olup daha sonra şehirleşme Kale ve çevresinde yoğunlaşmıştır (Uğur, 2004, s.41). Bölge, Mezopotamya'da Asur Devleti'nin kurulmasiyla M.Ö. 850612 yılları arasında Asur egemenliğinde kalmış, daha sonra Medler'in hâkimiyeti altına girmiş, M.Ö. 539-533 yılları arasında Perslerin eline geçen yöre, M.Ö. 333'te Pers Devletinin yıkılması ile birlikte Roma İmparatorluğu'na bağlanmış ve M.S. 395'e kadar Roma İmparatorluğunun hakim olduğu bölge sınır kenti iken, Roma İmparatorluğunun bölünmesi ile birlikte bölge MS 636 yılına kadar Bizans İmparatorluğunun yönetimine geçmiştir (Egeplan, 2020, s.12). Bölgedeki Antep, Dülük, Merziban, Raban, T1lbaşar Kaleleri, 639 y1lında Halife Ömer döneminde Bizanslılardan savaşsız alınmış, yapılan savaşlar sonucu bölge Bizans ve İslam topluluğu arasında el değiştirmiştir (Kuban, 2001,s.123).

11. yüzyıl sonlarına doğru Oğuzlar soyundan olan Türkmenlerin devamlı olarak yerleştiği bölge Türk egemenliğine girmiş, 1071 Malazgirt Savaşı sonrası Selçuklu İmparatorluğu'na bağlı bir Türk Devleti kurulmuş, 1270 yılında Moğolların istilası ile yıkılan kent, daha sonra Dulkadiroğullarının (1389) ve Memlüklülerin (1471) eline geçmiştir (Tatlıgil, 2005, s.12). 1516 yılında Memlüklüler'e karşı yapılan Mercidabık Savaşı ile Gaziantep ve yöresi Yavuz Sultan Selim tarafından Osmanlı İmparatorluğu'na katılmış; Osmanlı idaresinde önce Zulkadriye (Maraş) eyaletine bağlı bir sancak merkezi, daha sonra 1818'de ise Halep Eyaleti Merkez Sancağı'na bağlı kaza merkezi olmuştur. Osmanlının yükselme devrinde Osmanlı İmparatorluğu'na bağlanan Gaziantep'te bu dönemde yapılmış cami, mescit, medrese, han ve hamam sayısının çokluğundan da anlaşılacağ üzere bu dönem Gaziantep için de yükselme devri olmuştur (Şekil 4). Osmanlının gerileme devrinde ise kuraklık, deprem, 
veba salgını gibi olaylardan geniş ölçüde etkilenen Gaziantep de karışıklıklar olmuş, çeşitli başkaldırmalar görülmüştür (KUDEB, 2011, s.27)

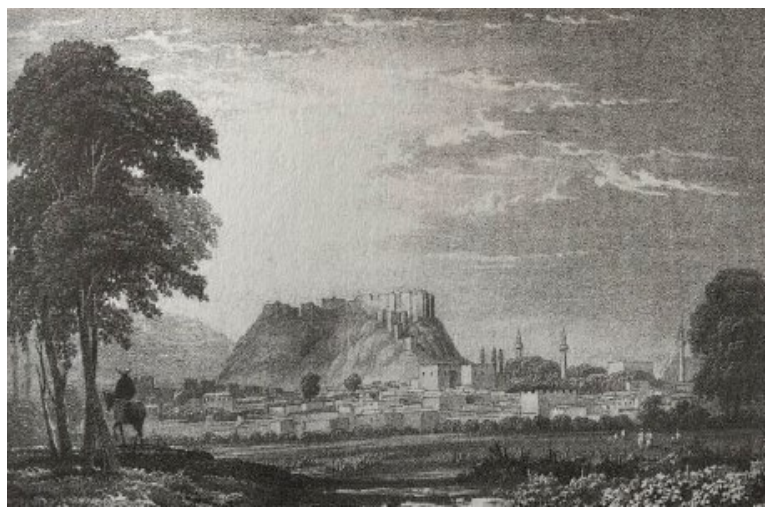

Şekil 4. Colonel Chesney Tarafından 1850’ de Yapılan Kent ve Kale gravürü. “Gaziantep kalesi kentli kale”, Akpolat, 2010, s.47 kitabından aynen alınmıştır.

1918'de imzalanan Mondros Mütarekesi sonucu Osmanlı Devleti'nin I. Dünya Savaşı'nda yenilgiyi kabul etmesi üzerine 1919' da önce İngilizler daha sonra Fransızlar tarafından işgal edilen kentte işgalin sürekli olduğu anlaşılmış ve kent halkı 1 Nisan 1920 de direnişe başlamış, 25 Aralık 1921'de de işgalden kurtulmuş, Ankara Antlaşması ile tescillenen bu zafer sonucunda kente 6 Şubat 1921'de T.B.M.M. tarafından “Gazi” lik unvanı verilmiş, Cumhuriyetin ilanı ile birlikte, 1924 yılında tüm sancaklar kaldırılarak Gaziantep il statüsüne kavuşmuştur (Özlü, 2017, s. 331). Kentin tarihi gelişim çizgisi incelendiğinde birçok farklı uygarlıkların etkisiyle şekillenen kültürel, sosyal, mimari birikimi günümüzde varlığını yapılarıyla, gelenek-görenekleriyle hala hissettirmektedir.

\section{Gaziantep Kenti Planlama Süreci}

Gaziantep kenti için hazırlanan ilk plan 1935 yılında Prof. Hermann Jansen tarafından hazırlanmıştır (Şekil 5) (Ay, 2001, s.44). 


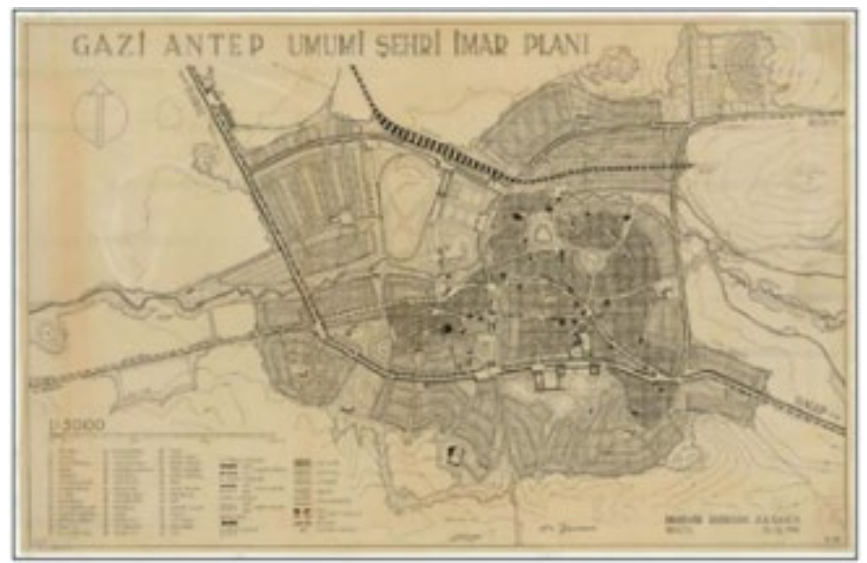

Şekil 5. 1935 Gaziantep Kenti İmar Planı. Gaziantep Büyükşehir Belediye Arşivinden aktarilmıştır.

Bu tarihten sonra 1950, 1974, 1990 ve 2011'de de kentin imar planında düzenlemeler yapılmıştır (Yenice ve Yenice, 2018, s. 554 ).

İlk imar planı olan 1935 Jansen Planı Gaziantep'in ilk kapsamlı ve bütüncül kent planı deneyimi, 1935 yılında Alman şehirci Herman Jansen tarafından hazırlanmış kentin 1935-1950 yılları arasındaki gelişmesini yönlendirmiştir. H. Jansen tarafından yapılan ilk planın ardından 1950 yılında hazırlanan Söylemezoğlu-Aru planına kadar geleneksel doku gelişirken, 1950 yılından sonra yaşanan hızlı nüfus artışı kentin makroformunda önemli değişiklikler meydana getirmiştir. 1974 yılında Zühtü Can ve ekibi tarafından hazırlanan üçüncü imar planında kent bir sanayi kenti modelini yansitmaktadır(Can, 2010, s.160). 1990 yılında Gaziantep Büyükşehir Belediyesi tarafından mevcut planlara ilave olarak yaptırılan ve hedef yıl olarak 2005 yılının belirlendiği $\mathrm{H}$. Oğuz Aldan tarafından hazırlanan Gaziantep kentinin dördüncü nazım imar planı olan İlave Nazım İmar Planı incelendiğinde kent artık büyükşehir modelini yansıtmaktadır. 5216 sayılı Büyükşehir Belediye Kanunu ile Gaziantep Büyükşehir Belediyesi sınırları genişlemiş ve 2011 yılında 1/25.000 Büyükşehir Nazım İmar Planı hazırlanarak Gaziantep Büyükşehir Belediye Meclisi tarafından onaylanarak yürürlüğe girmiştir (Yenice ve Yenice, 2018, s.559).

\section{Şehreküstü Bölgesi}

Örneklem alanı olarak seçilen Şehreküstü Bölgesi; Gaziantep kentinin tarihi dokusunda yer alan ve halen içinde yaşamın devam ettiği mahalle ve sokakların bulunduğu, geleneksel Antep evlerinin yoğun olarak bulunduğu fakat sosyal yapının dünden bugüne köklü bir değişim geçirdiği bir bölgedir. 
Bir dönem refah seviyesi yüksek ailelerin yaşadığı konakların bir bölümü bugün terk edilmiş olup, bir bölümü ise düşük gelirli veya kente göç yolu ile gelen ailelerin yaşadığı evler olarak kullanılmaktadır. Bölgenin iklim koşulları ve çevresel etkilere bağlı yıpranmaların yanı sıra kullanıc ihtiyaçlarına göre yapılmış eklentilerle birlikte sokak dokularında bozulmalar oluşmuş ve bölge sakinlerinin ekonomik durumları nedeniyle yapıların onarım ve bakımları yapılamamıştır. Ayrıca bölgeyle kültürel bağı olan kullanıcıların bölgeyi terk etmesi ve bölgenin yeni sakinlerinin bölgeyle olan kültürel bağının zayıf olması bölgenin çöküntü haline gelmesine, bölgedeki yapıların bakımsız kalmasına ve bölgenin geleneksel dokusunda bozulmalar meydana gelmesine sebep olmuştur.

Özellikle son dönemde Şahinbey belediyesi için öncelikli alanlardan olan aynı zamanda kentsel koruma sınırı içerisinde yer alan Şehreküstü Bölgesi'nde bütüncül koruma düşüncesiyle kentsel tasarım proje uygulamaları ve cephe sağlıklaştırma çalışmaları yapılmıştır.

Belediyenin bölgedeki çalışmaları sokak sağlıklaştırma, cephe yenileme, kentsel tasarım projelerinden oluşmuş ve dört etap halinde gerçekleştirilmiştir. Sokak sağlıklaştırma uygulaması ve restorasyon çalışmaları ile bu bölgenin eski tarihi dokusuna kavuşması amaçlanmıştır (Fotoğraf 1 ).
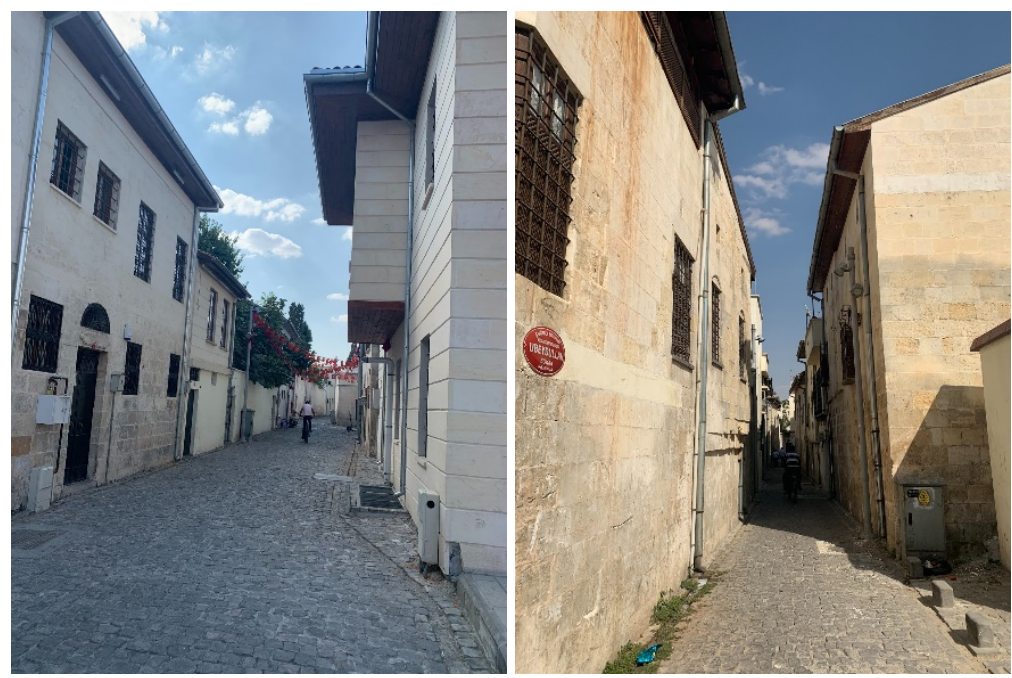

Fotoğraf. 1 Ubeydullah Sokak Görünümü 
Çalışmanın birinci etabı Suyabatmaz Mahallesi sokaklarında sokak sağlıklaştırma çalışmalarından oluşmaktadır. İkinci etap birinci kısım sokak sağlıklaştırma, kentsel tasarım uygulaması ile park yapım işini kapsamıştır (Fotoğraf 2).

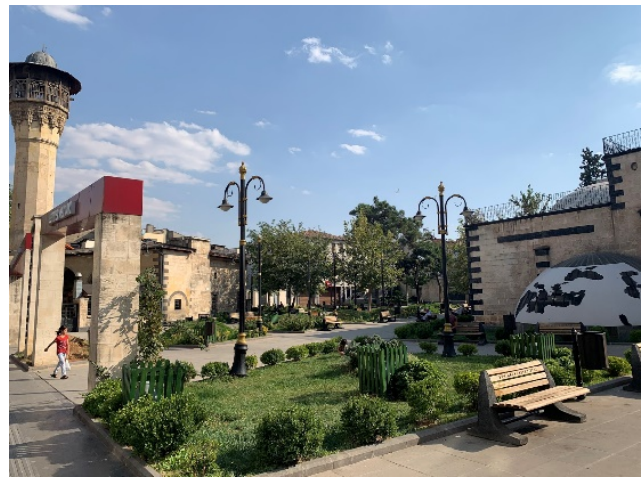

Fotoğraf 2. Şehitler Meydanı

İkinci etap ikinci kısımda ise Kozluca Mahallesi sokakları ve çıkmazlarında yirmi dört tescilli yapı ile birlikte geleneksel yapılarla sokak sağlıklaştırma projesi tamamlanmıştır. Üçüncü etap Kepenek ve Kocaoğlan Mahallesi sokak ve çıkmazlarında on sekiz tescilli yapı ile birlikte geleneksel yapılarla sokak sağlıklaştırma projesi tamamlanmıştır. Çalışmanın son kısmı olan dördüncü etap Ulucanlar Mahallesi sokak sağlıklaştırma ve kentsel tasarım projesini kapsamaktadır (Fotoğraf 3) (Şahinbey Belediyesi İmar ve Şehircilik Müdürlüğü Arşivi, 2020).

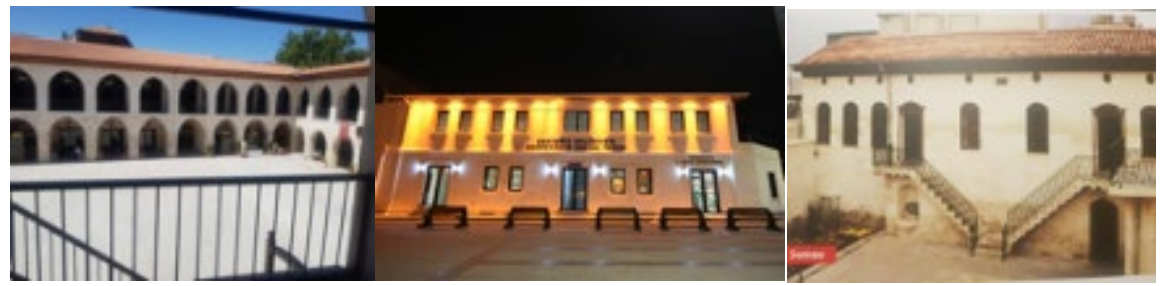

Fotoğraf 3. Tescilli yapı projeleri; Soldan sağa Mecidiye Han-Millet KıraathanesiHaleplizade Konağı

\section{Yöntem}

Kentsel yaşam kalitesinin tarihi çevrede ve bu bölge özelinde ölçülmesi için belirlenen parametrelerde, örneklem alanı olan Şehreküstü Bölgesi'nin derinlemesine araştırılması, kentin genel durumu, kentlinin bilhassa bu bölgede 
yaşayan yerel halkın beklentileri ön planda tutulmuştur. Yerel yönetimin uyguladığ 1 ihya projeleri ve bu projelerin sonucunda yerel halkın memnuniyeti ve beklentilerinin ne düzeyde karşılandığı sorularına cevap aranmıştır. Çalışmanın toparlayıcısı olarak belirlenen Şehitler Caddesi aksı da bulunduğu bölgenin ticari faaliyet zinciri ve diğer projelerle olan bağlantısı sebebiyle odak nokta seçilmiştir. Yöntem aşamaları; Literatür taraması, kentsel yaşam kalitesi parametrelerinin bölgedeki fonksiyonu değiştirilen yapılar bağlamında belirlenmesi, yerel halk ile anket çalışması yapılması ve anket sonuçlarının değerlendirilmesidir (Şekil 6.)

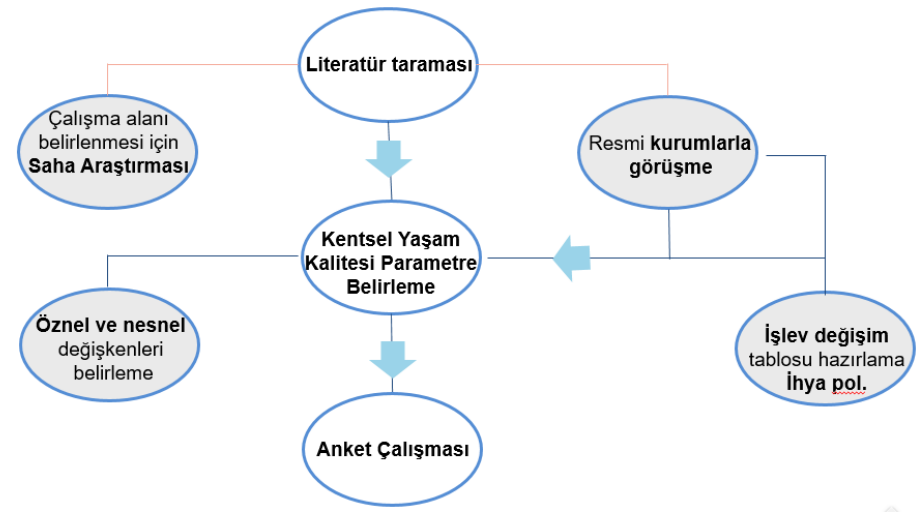

Şekil 6. Yöntem akışşseması

Uygulanacak aşamalardan ilki geniş bir literatür taraması olmuştur. Bu amaçla bölgede projelerine devam eden Şahinbey Belediyesi İmar ve Şehircilik Müdürlüğü ile görüşmeler yapılmış, alanda yerinde gözlem ve inceleme yapılmıştır. Böylece çalışma alanı sınırları belirlenmiştir (Şekil 7). Ayrıca çalışmanın başında da aktarılan kentsel yaşam kalitesi kavramının ne olduğu, nasıl ölçülebileceği, dünya ve yerelden örneklerle irdelenmiştir. Çalışma alanı içerisinde ihya edilen kültür varlıklarının neler olduğu, önceki ve günümüz kullanımları hakkında veri toplanmıştır. 


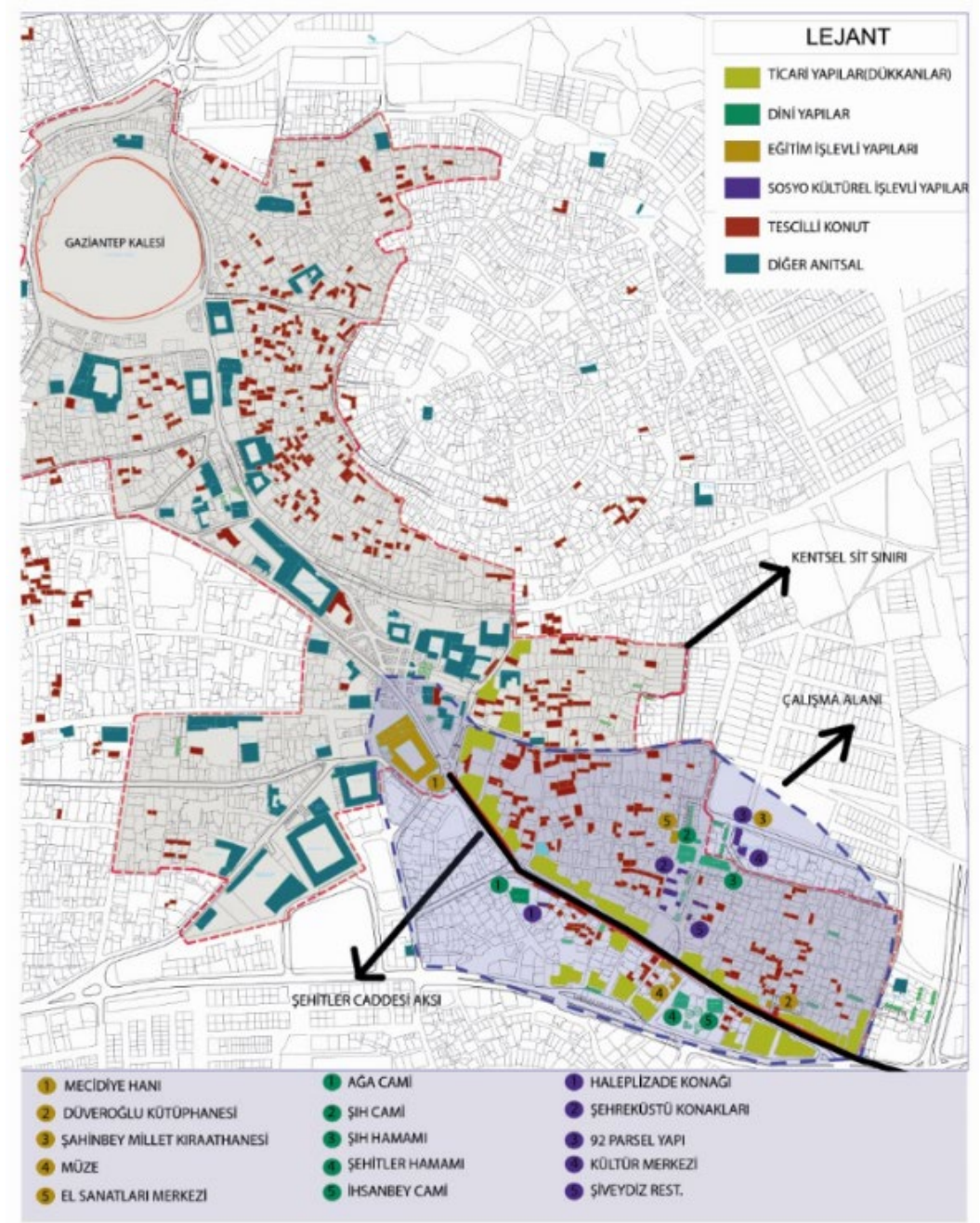

Şekil 7. Çalışma alanı sınırları.

Diğer aşama olan parametrelerin belirlenmesinde Şehreküstü Bölgesi'ndeki ihya edilen kamusal odak merkezlerinin işlev değişim tabloları hazırlanmıştır. Çalışma alanında belirlenen 16 adet tescilli yapı kamusal fayda düşüncesiyle ihya edilmiştir. Ayrıca Şehitler Caddesi aksındaki ticaret dokusunda bulunan ticarethanelerin cephelerinde sağlıklaştırma çalışmaları yapılmıştır. Bu değişimlerden bölge halkının memnuniyet durumlarının ölçülebilmesi için 138 katılımcıya anket yapılmıştır. Anket sonuçlarına göre yerelde kullanıcıların yaşam memnuniyeti sonuçlarına ulaşılmıştır. Belirlenen parametrelerin kendi içlerindeki durumları karşılaştırılmış, standart sapmada en 
yüksek değeri veren göstergenin en problemli alan olduğu belirtilmiştir. Standart sapma değeri en düşük olan göstergenin ise kentsel yaşam kalitesi bağlamında en olumlu sonuçta değerlendirildiği sonucuna varılmıştır.

Kentsel Yaşam Kalitesi Parametrelerinin Belirlenmesi

Parametrelerin belirlenmesi için öncelikle çalışma alanındaki kültür varlıklarının tespiti ve yapılan projelerin içeriklerine ulaşılmıştır. Yapıların fonksiyonlarındaki değişimler, önceki ve yeni kullanımları sınıflandırılmıştır. Ayrıca bu varlıkların hangi bölgelerde bulundukları tespit edilmiş, anket çalışması için ziyaret edilecek bölgeler tespit edilmiştir (bkz. Tablo 1.).

Tablo 1. Restorasyon ve sağlıklaştırma çalışmaları

\begin{tabular}{lccc}
\hline \multicolumn{1}{c}{ Yapılar } & Önceki Kullanım & Güncel Kullanım & Bulunduğu Bölge \\
\hline Mecidiye Hanı & Han & $\begin{array}{c}\text { Kütüphane- } \\
\text { Sahaflar çarşısı }\end{array}$ & Karagöz Mah. \\
\hline Şehreküstü Konakları-180 P. & Konut & $\begin{array}{c}\text { Restoran-kültür } \\
\text { merkezi }\end{array}$ & Kepenek Mah. \\
\hline Düveroğlu Kütüphanesi & Konut & Kütüphane & Kepenek Mah. \\
\hline $\begin{array}{l}\text { Helvacıkara Kıymık Geleneksel El Sa- } \\
\text { natları Merkezi }\end{array}$ & Konut & El Sanatları Kursu & Suyabatmaz Mah. \\
\hline 92 P. Yapı & Konut & El Sanatları Kursu & Kepenek Mah. \\
\hline Şıh Cami Evi & Konut & Kültür Evi & Suyabatmaz Mah. \\
\hline Şıh Hamamı & Hamam & Hamam & Suyabatmaz Mah. \\
\hline Haleplizade Konağ1 & Konut & Dizi çekim platosu & Suyabatmaz Mah. \\
\hline Şahinbey Milli Mücadele Müzesi & Konut-mağara & Müze & Ulucanlar Mah. \\
& (Savaş Müzesi) & Kanatları Merkezi & \\
\hline Şehreküstü Konakları & Kültür Evi & Kepenek Mah. \\
& Konut & Kütüphane & \\
\hline Pişirici Kasteli Mescidi & & Okuma Salonu & \\
\hline İhsan Bey Cami Kasteli & Kastel & Müze Kastel & Suyabatmaz Mah. \\
\hline Şı̆ Kasteli & Kastel & Müze Kastel & Kocaoğlan Mah. \\
\hline Ağa Cami & Kastel & Müze Kastel & Suyabatmaz Mah. \\
\hline Şehitler Caddesi & Cami & Cami & Suyabatmaz Mah. \\
\hline $\begin{array}{l}\text { Şehreküstü Sosyal Tesisi-Millet } \\
\text { Kıraathanesi }\end{array}$ & Konut & $\begin{array}{c}\text { Kültür merkezi - } \\
\text { Okuma salonu }\end{array}$ & Suyabatmaz Mah. \\
\hline
\end{tabular}

Bölgedeki ihya edilen yapıların yeni fonksiyon türleri; kültür merkezi, müze, el sanatları kursu, restoran, kütüphane gibi çoğunlukla sosyo-kültürel değerde olmuştur. Bölgedeki fonksiyonların hangi parametrelere karşlık gelebileceğini tespit edebilmek adına $\mathrm{OECD}, \mathrm{BM}, \mathrm{AB}$ 'nin çalışmalarında belirlediği kentsel yaşam kalitesi göstergeleri incelenmiş ve bunlardan çalışmada kullanılacak yeni fonksiyonlara karşılık gelen kentsel yaşam kalitesi parametreleri tespit edilmiştir (Şekil 8). 


\begin{tabular}{|c|c|c|c|}
\hline $\begin{array}{l}\text { OECD- Daha lyi } \\
\text { Yaşam Endeksi }\end{array}$ & $\begin{array}{c}\text { BM- Kentsel } \\
\text { Göstergeler Programı }\end{array}$ & AB - Kentsel Denetim Çalışması & $\begin{array}{c}\text { Çalış̧mada Kullanılan } \\
\text { Parametreler }\end{array}$ \\
\hline Konut & Konut & Konut & Konut \\
\hline $\begin{array}{l}\text { Gelir, Istihdam } \\
\text { Iş-yaşam dengesi }\end{array}$ & Ekonomik Gelişme & $\begin{array}{l}\text { Ekonomik Faaliyet, } \\
\text { Gelir Eşitsizliği ve } \\
\text { Yoksulluk, Işgücü Piyasası }\end{array}$ & Ekonomi ve Istihdam \\
\hline Çevre & Çevre & $\begin{array}{l}\text { Iklim ve Coğrafya, Atık Yönetimi, Hava kalit } \\
\text { esi, Su, Arazi Kullanımı, Enerji Kullanımı }\end{array}$ & Çevre \\
\hline Toplum & Sosyal Gelişme & $\begin{array}{l}\text { Hane halkı yapısı, Nüfus, Vatandaşlık, Turiz } \\
\text { m, Külttür ve eğlence }\end{array}$ & Sosvo -kültürel \\
\hline Sivil katılım & Yönetişim & Vatandaş Katılımı & Katilım \\
\hline Eğitim & - & $\begin{array}{l}\text { Nüfusun Eğitim Durumu- } \\
\text { Eğitim Hizmetleri Sunumu }\end{array}$ & Eğitim \\
\hline Güvenlik & - & Suç & Güvenlik \\
\hline Yaşam memnuniyeti & - & - & Yaşam Memnuniyeti \\
\hline Sağlık & - & Sağlık & - \\
\hline - & - & Ulaşım & Ulaşım \\
\hline
\end{tabular}

Şekil 8. Parametreler için temel alınan uluslararası kurumlar ve göstergeleri. "Kentsel yaşam kalitesi ölçüm yöntemlerinin geliştirilmesi”, İnan ve Sönmez, 2019, s. 192-193 makalesi temel alınarak yazarlar tarafından oluşturulmuştur.

\section{Anket Sorularının Belirlenmesi}

Belirlenen parametreler; konut, çevre, sosyo-kültürel, ekonomi ve istihdam, eğitim, güvenlik, ulaşım, katılım, yaşam memnuniyeti olmuştur. Bunların ankete aktarılmasında her yapı türünün bölgeye kattığı değerler belirlenip onun altında metadata olarak soruların oluşturulması aşaması gerçekleştirilmiştir. Sorular, en yüksek 5 en düşük 1 puan olmak üzere belirli puan dereceleriyle çoktan seçmeli olarak kullanıcılara iletilmiştir. Puanlama sonuçları, bulgular kısmında değerlendirilecektir.

Anketlerin değerlendirilmesinde 5'li likert ölçeği kullanılmıştır. Bu ölçek, orijinalinde 5 seçenekten oluşan, katılım düzeyini belirlemek amacıyla iki uç derece arasındaki birden çok derece ile seçeneğin sunulduğu bir analiz aracldır. Böylece nitel veriler nicel verilere dönüştürülerek değerlendirme imkânı oluşur (Turan vd., 2015, s.188). Cevap seçenekleri: Çok kötü, kötü, orta, iyi, çok iyi olarak belirlenmiş, çok iyi 5; çok kötü 1 puan olmak üzere puanlama yapılmıştır. Uzman görüşü olarak sağlanması gereken değer ortalama 5 olarak verildiğinden ortalama değer üzerinden, standart sapma değeri en yüksek olan gösterge en olumsuz sonuç olarak belirlenmiştir. Bu durumda;

Aralık Genişliği= (En yüksek puan derecesi-En düşük puan derecesi) / (Kullanılan Puan Sayısı) formülünden,

$4 / 5=0,80$ (Puan aralığı) olarak belirlenmiştir. Böylece;

1-1,79(çok kötü), 1,80-2,59(kötü), 2,60-3,39(orta), 3,40-4,19(iyi), 4,205,00(çok iyi) aralıkları derecelendirme ölçütü olmuştur. 
Göstergelere ve ihya edilen kültür varlıklarına göre hazırlanan sorular toplamda 18 adettir. Bunlardan ekonomik göstergeye karşlık gelen: bireysel ekonomik düzey, bölgesel iş imkânları, turizm potansiyelinin ekonomik karşılığının kullanılması konusunda 3 soru sorulmuştur. Sosyo-kültürel göstergeye karşılık gelen: aidiyet hissi, koruma bilinci, sosyal donatı yeterliliği, genel kültür besleyici durumu konusunda 4 soru sorulmuştur. Eğitim göstergesinde, kurs birimlerinin yeterliliği, okuma salonu etkisi, millet kıraathanesi konusunda 3 soru sorulmuştur. Güvenlik göstergesine karşıllk olarak güvenlik koşullarının genel durumu ve gece güvende hissetme durumuna dair 2 soru sorulmuştur. Ulaşım göstergesi için, alana ulaşım koşulları ve toplu ulaşım yeterliliği alt göstergesinde 2 soru sorulmuştur. Yaşam memnuniyeti göstergesinde engelli kullanıcıların memnuniyeti ile ilgili 1 soru, katılımcılık göstergesinde $1 \mathrm{soru}$, çevre göstergesinde rekreatif düzenlemelerle ilgili 1 soru ve son olarak bölgedeki konutların fiziki kalitesinin yaşam kalitesine etkisine yönelik 1 soru sorulmuştur.

\section{Bulgular}

Çalışma alanı olarak belirlenen bölgede yapılan anketlerin sonuçlarına göre ankete Kozluca Mah., Suyabatmaz Mah., Ulucanlar Mah. ve Kepenek Mahallesinde toplam 138 katılımcı katılmıştır (Şekil 9).

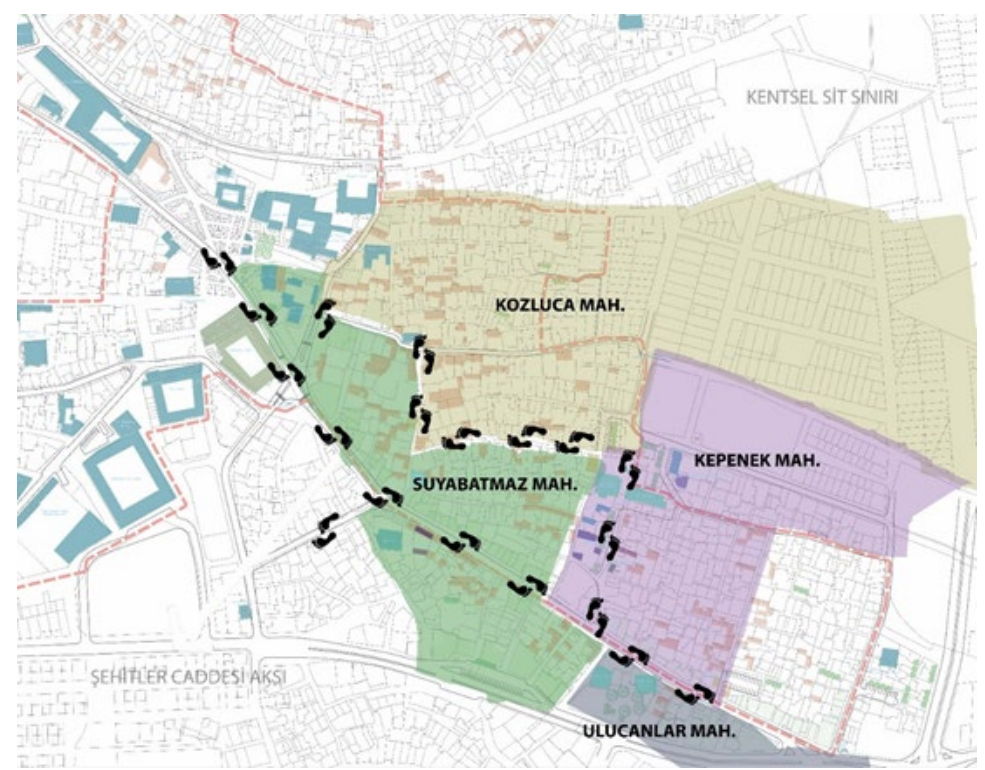

Şekil 9. Katılımcıların yaşadıkları mahalleler ve anketör güzergâhı 
Demografik bulgulara göre katılımcılar yoğunluklu olarak 45-65 yaş arasindadır (bkz. Tablo 2). Katılımcıların \%70'i erkek,\%30'u kadındır. Kadın ve erkek katılımcıların eğitim seviyelerine bakıldığında katılımcıların yarısı ortaöğretim mezunudur (bkz. Tablo 3). Anket katılımcıları arasında lisansüstü eğitim seviyesi oranı düşüktür.

Tablo 2. Katılımcıların yaşlarına göre dağılımı

\begin{tabular}{lrr}
\hline Yaş & $\mathbf{N}$ & $\%$ \\
\hline $18-25$ & 14 & 10 \\
\hline $26-45$ & 39 & 28 \\
\hline $46-65$ & 65 & 47 \\
\hline 66 ve üzeri & 20 & 15 \\
\hline Toplam & 138 & 100,0 \\
\hline
\end{tabular}

Tablo 3. Cinsiyete göre adayların eğitim durumuna ilişkin dağılım.

\begin{tabular}{lcccc}
\hline \multicolumn{5}{c}{ Ĕ̆itim durumu } \\
\hline Cinsiyet & Ilköğretim & Ortaöğretim & Lisans & Lisansüstü \\
\hline Kadın & $\%$ & $\%$ & $\%$ & $\%$ \\
\hline Erkek & 10 & 15 & 5 & 0 \\
\hline Toplam & 10 & 35 & 24 & 1 \\
\hline
\end{tabular}

Katılımcılara yapılan anket sonuçlarına göre göstergeler puanlanmıştır. Buna göre en yüksek değere sahip 3,91 değerle çevre göstergesi ardından 3,62 ile sosyo-kültürel gösterge olmuştur. En düşük gösterge değerine ise 2,2 ile güvenlik ve 2,21 ile katılımclık göstergeleri olmuştur (Şekil 10).

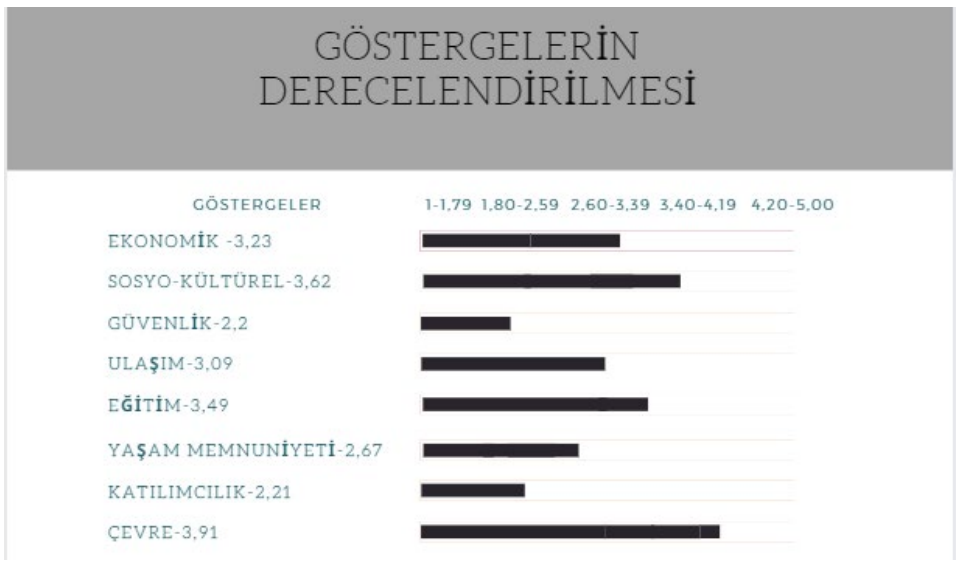

Şekil 10. Göstergelerin sonuçları 
En düşük puanlamaya sahip olan güvenlik göstergesindeki sorular yerel halkın bölgeden duydukları güvenlik endişelerini açığa çıkartmıştır (Şekil 11). Özellikle hırsızlık, madde kullanımı gibi olumsuz ortam koşullarının yapılan ihya çalışmalarına rağmen düzelememiş olması yaşam kalitesini olumsuz etkilemektedir. Alanın yerel kullanıcılar tarafından terk edilmesi, göç ile gelen yeni halkın bölgeyi benimsenmemesi, yeni kullanıcıların sosyo-ekonomik yönden düşük potansiyelde olmasl, alanda yeteri kadar güvenlik önlemlerinin alınmamış olması gibi durumlar güvenlik açığına neden olmaktadır.

\begin{tabular}{|c|c|c|c|c|c|c|}
\hline & $\begin{array}{c}\text { ÇOK } \\
\text { KöTÜ(1 P.) }\end{array}$ & $\begin{array}{l}\text { KÖTÜ (2 } \\
\text { P.) }\end{array}$ & $\begin{array}{l}\text { ORTA(3 } \\
\text { P.) }\end{array}$ & IYYi (4 P.) & $\begin{array}{l}\text { ÇOK IYYi (5 } \\
\text { P.) }\end{array}$ & TOPLAM \\
\hline $\begin{array}{c}\text { 8. SORU } \\
\text { (Güvenlik koşulları) }\end{array}$ & $40 \mathrm{P}$ & $84 \mathrm{P}$ & $126 P$ & $84 \mathrm{P}$ & $15 P$ & $\begin{array}{c}339 \mathrm{P} / 138 \\
\mathrm{~K}=2,45\end{array}$ \\
\hline $\begin{array}{c}\text { 9.SORU } \\
\text { (Gece güvenlik) }\end{array}$ & $69 \mathrm{P}$ & $42 \mathrm{P}$ & $99 \mathrm{P}$ & $60 \mathrm{P}$ & $0 P$ & $\begin{array}{c}270 \mathrm{P} / 138 \mathrm{~K} \\
=1,95\end{array}$ \\
\hline ORTALAMA & & & & & & 2,2 \\
\hline
\end{tabular}

Şekil 11. Güvenlik göstergesi sonuçları

Bölgede yaşayan yerel halkın kentsel yaşam kalitesinin artırılması konusunda katılımcılık önemli bir olgudur. Bölgenin kalkınması için yerel yönetimlerin yapacakları projelerde karar verme aşamasında, uygulama aşamasında ve sonuçları değerlendirme aşamasında en önemli faktör olan kullanıcının düşünce ve önerilerini dikkate almaları gerekir. Bu durumun sağlanması kentsel kalitenin, yaşam memnuniyetinin artışını sağlar. Anket sonuçlarına göre yerel yönetimin Şehreküstü Bölgesi için yapmış olduğu çalışmalarda yeterli düzeyde katılımcılık konusunun ön planda tutulmadığı, kullanıcıların fikirlerinin alınmadığı ortaya çıkmıştır (Şekil 12).

\begin{tabular}{|c|c|c|c|c|c|c|}
\hline & $\begin{array}{c}\text { çOK KÖTÜ } \\
\text { (1 P.) }\end{array}$ & КÖтÜ (2 P.) & $\begin{array}{l}\text { ORTA } \\
\text { (3 P.) }\end{array}$ & îyi (4 P.) & çoK IYi (5 P.) & TOPLAM \\
\hline $\begin{array}{l}\text { 2. SORU } \\
\text { (Halkın karar vermede } \\
\text { görüşleri) }\end{array}$ & $51 \mathrm{P}$ & $78 \mathrm{P}$ & $72 \mathrm{P}$ & $60 \mathrm{P}$ & $45 \mathrm{P}$ & $\begin{array}{rl}306 & P / 138 \mathrm{~K} \\
& =2,21\end{array}$ \\
\hline ORTALAMA & & & & & & 2,21 \\
\hline
\end{tabular}

Şekil 12. Katılımclık göstergesi sonuçları

En yüksek dereceli göstergeler: çevre, ekonomi ve sosyo-kültürel göstergeler olmuştur. Rekreasyon alanlarındaki düzenleme, meydan genişletme çalışmaları, organik sokak dokusu düzenlemesi, aydınlatma elemanları, peyzaj mobilyaları kullanımı halkın memnuniyetini sağlamıştır (Şekil 13). 


\begin{tabular}{|c|c|c|c|c|c|c|}
\hline & $\begin{array}{c}\text { ÇOK KÖTÜ } \\
\text { (1 P.) }\end{array}$ & КӧтÜ (2 P.) & $\begin{array}{l}\text { ORTA } \\
\text { (3 P.) }\end{array}$ & îyi (4 P.) & çOK IYY (5 P.) & TOPLAM \\
\hline $\begin{array}{l}\text { 12. SORU } \\
\text { (Rekreatif } \\
\text { düzenlemeler) }\end{array}$ & $0 P$ & $30 \mathrm{P}$ & $54 \mathrm{P}$ & $276 \mathrm{P}$ & $180 \mathrm{P}$ & $\begin{array}{c}540 \mathrm{P} / 138 \mathrm{~K} \\
=3,91\end{array}$ \\
\hline ORTALAMA & & & & & & 3,91 \\
\hline
\end{tabular}

Şekil 13. Çevre göstergesi sonuçları

Sosyo-kültürel sürekliliğin sağlanabilmesi için kültür varlıklarının yeniden kullanımlarında yerel halkın yararlanabileceği, kültürel kapasitelerini artırabileceği, eğitim alabileceği, sosyal donatılar sağlanmıştır. En yüksek alt gösterge aidiyet hissinin sürekliliğinin sağlanması olmuştur. Bu durum yapılan restorasyon, sokak sağlıklaştırma çalışmalarının kentin hafızasındaki dokuyu canlandırmasına katkıda bulunduğunu göstermektedir (Şekil 14).

\begin{tabular}{|c|c|c|c|c|c|c|}
\hline & $\begin{array}{l}\text { ÇOK KÖTÜ } \\
\text { (1 P.) }\end{array}$ & KÖTÜ (2 P.) & $\begin{array}{l}\text { ORTA } \\
\text { (3 P.) }\end{array}$ & îyi (4 P.) & çOK IYYi (5 P.) & TOPLAM \\
\hline $\begin{array}{c}\text { 1. SORU } \\
\text { (Aidiyat hissi) }\end{array}$ & 0 & 0 & $90 \mathrm{P}$ & $168 \mathrm{P}$ & $330 \mathrm{P}$ & $\begin{array}{c}588 \mathrm{P} / 138 \mathrm{~K} \\
=4,26\end{array}$ \\
\hline $\begin{array}{l}\text { 3.SORU } \\
\text { (Koruma-kültür) }\end{array}$ & 0 & $18 \mathrm{P}$ & $90 \mathrm{P}$ & $204 P$ & $240 P$ & $\begin{array}{c}552 \mathrm{P} / 138 \mathrm{~K} \\
=4\end{array}$ \\
\hline $\begin{array}{c}\text { 5.SORU } \\
\text { (Sosyal donatı } \\
\text { yeterliliği) }\end{array}$ & $3 P$ & $42 \mathrm{P}$ & $54 \mathrm{P}$ & $300 \mathrm{P}$ & $105 \mathrm{P}$ & $\begin{array}{l}504 \mathrm{P} / 138 \mathrm{~K} \\
\quad=3,65\end{array}$ \\
\hline $\begin{array}{c}\text { 15.SORU } \\
\text { (Genel kültür) }\end{array}$ & $27 \mathrm{P}$ & $84 \mathrm{P}$ & $117 \mathrm{P}$ & $72 P$ & $60 \mathrm{P}$ & $\begin{array}{c}360 \mathrm{P} / 138 \mathrm{~K} \\
=2,60\end{array}$ \\
\hline ORTALAMA & & & & & & 3,62 \\
\hline
\end{tabular}

Şekil 14. Sosyo-kültürel gösterge sonuçları

Ekonomi göstergesi de diğer göstergelere oranla iyi puan almıştır. Bunda yapılan çalışmaların her ne kadar pandemi sürecinden etkilenmesi durumu olsa da dizi çekim platosu olarak kullanılan restore edilmiş mekânların varlığı, alanın iyileştirilme çalışmaları turist çekiciliği anlamında olumlu adımlar olmuştur. Dikkat çeken nokta bireysel düzeydeki ekonomik yeterliliğin bölgesel düzeyden yüksek olduğu görüşüdür. Bu durum gelir düzeylerinde adaletsizliğin olabilmesi durumuna neden olabileceğinden bölgede yapılan ekonomi ağırlıklı projelerde hassas adımlar atılması gerektiğini göstermektedir (Şekil 15). 


\begin{tabular}{|c|c|c|c|c|c|c|}
\hline & $\begin{array}{c}\text { ÇOK KÖTÜ } \\
\text { (1 P.) }\end{array}$ & KÖTÜ (2 P.) & $\begin{array}{l}\text { ORTA } \\
\text { (3 P.) }\end{array}$ & iYyi (4 P.) & çOK iYi (5 P.) & TOPLAM \\
\hline $\begin{array}{c}\text { 6. SORU } \\
\text { (Bireysel Ekonomik } \\
\text { Düzey) }\end{array}$ & $3 P$ & $48 \mathrm{P}$ & $54 \mathrm{P}$ & $288 \mathrm{P}$ & $180 \mathrm{P}$ & $\begin{array}{c}453 \mathrm{P} / 138 \mathrm{~K} \\
=3,28\end{array}$ \\
\hline $\begin{array}{c}\text { 7.SORU } \\
\text { (Bölgesel İş İmkanları) }\end{array}$ & $9 \mathrm{P}$ & $78 \mathrm{P}$ & $72 \mathrm{P}$ & $180 \mathrm{P}$ & $105 \mathrm{P}$ & $\begin{array}{c}444 \mathrm{P} / 138 \mathrm{~K}= \\
3,21\end{array}$ \\
\hline $\begin{array}{c}\text { 18.SORU } \\
\text { (Turist Çekiciliğinin } \\
\text { Ekonomik Etkisi) }\end{array}$ & $9 \mathrm{P}$ & $60 \mathrm{P}$ & $117 \mathrm{P}$ & $168 \mathrm{P}$ & $90 \mathrm{P}$ & $\begin{array}{c}444 \mathrm{P} / 138 \\
\mathrm{~K}=3,21\end{array}$ \\
\hline ORTALAMA & & & & & & 3,23 \\
\hline
\end{tabular}

Şekil 15. Ekonomik gösterge sonuçları

\section{Tartışma ve Sonuç}

Kentlerin yaşam kalitesi, birçok farklı boyutta incelenebilir. Bu çalışmada özellikle tarihi kentlerin ve bu kentte yaşayan yerel halkın ihya politikaları sonucunda yaşam kalitesi memnuniyet düzeyi ölçülmüştür. Gaziantep Şehreküstü Bölgesi'nde bulunan 4 mahalle ölçeğinde yapılan çalışmada ana aks olarak seçilen Şehitler Caddesi aksı ve bu aksın yakın çevresinde bulunan tescilli yapılardan özellikle ihya politikaları ile doğrudan ilişkili olanlar seçilmiştir. Bu değişim ve dönüşümün kentlinin yaşamında etkisinin ne düzeyde olduğunu tespit edebilmek amacıyla ulusal ve uluslararası göstergeler filtreden geçirilerek sonuç göstergeleri oluşturulmuştur. Göstergelerin puan bazında ortalaması 3.06 olarak tespit edilmiştir bu da genel ölçüte vurulduğunda kalite durumunun ortalama olduğunu göstermektedir. Yapılan uygulamaların olumlu ve olumsuz yönleri bulunmaktadır. Bu sonuçların öncelikle bu bölge özelinde yerel yönetimlere yol gösterici olması umut edilmektedir. Sonraki çalışmalarda tarihi kentlerde yaşam kalitesi ölçümü üzerine farklı bir bakış açısı getirebilmek amaçlanmıştır.

Çalışmanın sonuçları değerlendirilecek olursa, öncelikle engelli kullanıcılar için insan odaklı bir anlayışla kentsel yaşam kalitesini arttıracak bazı önlemler alınmalıdır. Bunlar; engellilere yönelik rampa, yönlendirici şeritler, dokunmatik yönlendirici ekranların alan içinde uygun noktalarda kullanılması önerisi getirilebilir.

Bölgenin tarihi yapısından dolayı kırılgan olması beklenmektedir. Bu nedenle bölge için hassas düzeyde yaklaşılması gereken diğer önemli unsur turist kullanıcılar olmaktadır. Alana ilk defa gelen yabancı turistler için bu konuda yeterli düzeyde bilgilendirici levha, yönlendirme tabelası mevcut değildir. Yerli turistler için ise alanın çekim merkezi potansiyeli yüksek olmasına rağmen tanıtım eksikliği probleminden dolayı ziyaretçi sayısı yeterli düzeyde değildir. Büyükşehir Belediyesi'nin Kültür Yolu Projesi'nin devamı 
olan akstaki Şehitler Caddesi'nin, kaleden gelen aksla birleştiği noktada sağlıklaştırma çalışmaları ve restorasyon faaliyetlerinde kopukluk olması turistlerin ziyaret sırasındaki sürekliliğini olumsuz etkilemektedir. Böylece bölgeye ulaşma talebi azalmaktadır.

Pandemi süreci tüm dünyayı olduğu gibi alanı da etkilemiştir. Turizm ile bağlantısı yüksek olan kültür yapılarının ziyaretlerinde kısıtlamalara gidilmesi, bölgede turist faktörü ile iş yapan sektörlerin ekonomik olarak zarara uğramaları gibi nedenler yapılan ihya çalışmalarından ekonomik odaklı kalkınma beklentisini karşılayamamıştır.

Alana ulaşım konusu ise yapılan son çabalarla iyileştirilmeye çalışılmıştır fakat henüz trafik problemi tam olarak çözülememiştir. Yayalaştırma yapılan alanlar, yaya odaklı genişletilen meydanlar kullanıcıları yürümeye teşvik etmede olumlu bir adımdır fakat bölgede yaşayan kullanıcılar tarafından otopark ve ulaşım sisteminde tam olarak beklenti karşılanmamıştır.

Alanda en büyük problem hem katılımclara yapılan anketler hem de çalışmaları gerçekleştiren yerel yönetimlerle yapılan görüşmeler sonucu "Güvenlik sorunu" olarak belirlenmiştir. Özellikle hırsızlığın çok fazla olması, restorasyonda kullanılan malzemelerin çalınması, geceleri sokaklarda güvenli hissedilmeme gibi unsurlar alanda ciddi problemler meydana getirmektedir. Bu durum bölgede yaşayan ve bölgeyi ziyaret eden halkın da yaşam kalitesini olumsuz etkilemektedir.

Gaziantep bulunduğu bölge, ekonomik potansiyel ve ticaret hacmi gibi etkenler itibariyle çok fazla göç alan bir şehirdir. Sadece ülke içinde değil s1nıra olan yakınlığıyla özellikle mülteci göçünün yaşandığı bir bölgededir. Gaziantep kent merkezinin tarihi alanlardan oluşması ve kentin odak noktası olan bu alanlardan yerel ev sahiplerinin başka yeni kentleşen bölgelere göç etmesi ile evleri düşük gelirli ailelere kira vermesi durumu gerçekleşmiştir. Bu durum, yapılan kültürel canlılığı artırıcı politikaların sonuç vermede beklentiyi karşılayamamasına neden olmaktadır. Bölge ile hiçbir bağı bulunmayan insan gruplarının alanda yaşıyor olması koruma bağlamında yerelliği, gelenekselliği olumsuz etkilemiştir. Bu konu çok daha derin ve parametreleri çeşitli olan bir konu olup ayrı bir çalışmada ele alınabilir.

Valetta İlkeleri (2011)'nde de belirtildiği gibi yerel toplumların bireysel yaşam şekillerindeki değişimler, geleneksel ritüellerinden uzaklaşmaları tarihi kentlerin sürekliliğini olumsuz etkilemektedir. Bu durum o bölgede yaşayanların alanlarını terk etmelerine böylece geride kalan yerde geleneklerin kaybolmasına, belleğin yitimine neden olabilir. Bu alanların sadece turizm yoluyla yaşatılması ve tatile yönelik işlev verilmesi korumanın tam anlamıyla 
gerçekleştirilemediğini göstermektedir. Tarihi kentlerin korunabilmeleri, geleneksel sanatların devam ettirilmesine ve yerel halkın alanların terk etmemelerine bağlıdır (Valetta İlkeleri, 2011).

Ayrıca bu çalışma, 2012 Kyoto çerçevesinde sunulan ‘World Heritage and Sustainable Development: the Role of Local Communities' başlı̆ı̆ının irdelenmesi üzerine de iyi bir örnek oluşturmaktadır. Paris Deklerasyonu'nda belirtildiği şekilde; çabalar sadece tarihi binaları korumak değil bu binaların kullanımı, tanıtımı ve geliştirilmesini ekonomi, sosyal, kültürel değerlerle bağdaşarak yerel halkın yararına kullanılmasını desteklemelidir (Paris Deklarasyonu, 2011, s. 4).

Çalışmada en olumlu görülen göstergelerden biri sosyo-kültürel gösterge olmuştur. Sosyo-kültürel amaçlara yönelik başarılı bulunan çalışmalar bu bağlamda en başarılı olan ikinci unsur olmuştur. ICOMOS Kültürel Miras Alanların Algılanması ve Sunumu Tüzüğü (2008)'nde yer alan “...uygulanacak planlar; eğitim, öğretim ve istihdam firsatları yoluyla tüm paydaşlara eşit ve sürdürülebilir, ekonomik, sosyal ve kültürel faydalar sağlamayı amaçlamalıdır" ibaresine esas oluşturacak şekilde fonksiyonlarda sosyo-kültürel parametrelerin oluşturulması ve ölçülmesinde temel alınan nokta buradan yola çıkılarak yorumlanmıştır. Yapılan çalışmada yerel yönetimlerin bölgeye sunduğu imkânlar korumacı gözüyle bakılarak yorumlanmış ve kentsel yaşam kalitesine bu açıdan katkı konulmaya çalışılmıştır. Gelecek çalışmalarda farklı disiplinlerin katkılarıyla geniş ölçekte kalite standartları ve ölçümleri genişletilebilir. 


\section{Extended Abstract}

\section{The Effect Of Local Governments' Recovering Policies in Historical Landscape On Quality Of Life: Gaziantep Şehreküstü District}

\author{
Gamze Özmertyurt \\ ORCID: 0000-0002-0813-5503
}

\author{
İclal Sena Uncuoğlu \\ ORCID: 0000-0003-2510-1070
}

Currently, plans and projects, which are considered to increase the urban welfare level of local governments in cities and for the sustainability of the city, include variables that need to be decided in different dimensions, especially in the historical environment. There is a risk that local identity and heritage values will be left behind in commercially-oriented developing and growing cities, especially in the historical texture of the city. For this reason, it is important to consider urban quality together with the concept of heritage. The aim of the study is to highlight the sustainable power of cultural heritage in our developing and growing world, and to create a guide that will guide local governments in planning functions that can meet today's humanitarian quality of life expectations. The Şehreküstü district selected within the scope of the study was chosen for reasons such as its historical and cultural characteristics, the increase in the conservation activities of the local administration on this region.

Urban life quality is a concept that includes social, cultural and political elements and their processes. As local governments play a leading role in the realization of sustainable development, city plans that determine a better quality of life for cities have begun to be created. Therefore, the measurement of quality of life can be measured by developing measurement methods that can be shaped according to region-specific variables. For the parameters that will be used for the realization of the measurements, the activities of the organizations accepted in the world have been investigated. International institutions such as OECD, UN-Urban Indicators Program and EU-Urban Audit Study also set indicators and specified parameters for the measurement of urban quality. 
The Şehreküstü District, which has been chosen as the sampling area, is located in the historical texture of the city of Gaziantep, where there are neighborhoods and streets where life still continues, traditional Antep houses are concentrated, but the social structure has undergone a radical change from past to present. Some of the mansions where wealthy families once lived have been abandoned today, and some of them are used as low-income or migrant families. Recently, urban design project applications and façade rehabilitation studies have been carried out in the Şehreküstü District, which is one of the priority areas for Şahinbey municipality and is also located within the urban protection boundary. That projects were carried out in Suyabatmaz, Kozluca, Kepenek, Kocaoğlan and Ulucanlar Neighborhoods. In the parameters determined to measure the quality of urban life in the historical environment and specific to this region, the general condition of the city, the expectations of the local people living in this region, especially the city residents, have been prioritized.

Method of the study; Literature review, determining of urban quality of life parameters in the context of the buildings whose functions have been changed in the region, conducting a survey with residents and evaluating the results of the survey. In determining the parameters, function change tables of the revitalized 16 registered buildings and commercial fabric on the Şehitler Caddesi axis in the Şehreküstü District were prepared. In order to measure the satisfaction of the people of the region from these changes, a survey was conducted with 138 participants operating in the specified neighborhoods. According to the survey results, the life satisfaction results of the local users have been reached. According to demographic findings, the participants are mostly between the ages of $45-65.70 \%$ of the participants are men and 30\% are women.

Accordingly, the environmental indicator with the highest value of 3.91 was followed by the socio-cultural indicator with 3.62. The lowest indicator value was the security indicators with 2.2 and participation indicators with 2.21. The questions on the security indicator, which has the lowest scoring, revealed the security concerns of local people from the region. The quality of life of cities can be examined in many different dimensions. In this study, quality of life satisfaction level was measured as a result of the revival policies of especially historical cities and local people living in this city. The average score of indicators was found to be 3.06. This shows that the quality value is average.

If the results of the study are evaluated, first of all, some precautions should be taken to increase the quality of urban life for disabled users with a humanoriented approach. Due to the historical structure of the region, it is expected to 
be fragile. For this reason, another important factor that should be approached at a sensitive level for the region is the tourist users.

For foreign tourists coming to the area for the first time, there are not enough informative and direction signs. For local tourists, although the area has a high potential of attraction, the number of visitors is not sufficient due to the lack of publicity. The Covid 19 Pandemic has affected the whole world as well as the study area. Transportation to the area has been tried to be improved with the latest efforts, but the traffic problem has not been fully solved yet.

The biggest problem in the area has been identified as a "security problem" as a result of both the surveys conducted with the participants and the interviews with the local administrations. Factors such as excessive theft, theft of materials used in restoration, and not feeling safe in the streets at night cause serious problems. The fact that the city center of Gaziantep consists of historical areas and the local residents migrate from these areas, which are the focal points of the city, to the newly urbanized areas and rent their houses to lowincome families. This situation causes the policies that increase cultural vitality to fail to meet the expectations.

In the study, the opportunities offered to the region by local governments were interpreted with a conservative perspective and it was tried to contribute to the quality of urban life in this respect.Quality standards and measurements can be developed on a large scale with the contributions of different disciplines in future studies.

\section{Kaynakça/References}

Akdamar, E. (2018). ISO 37120:2014 Standardının akıllı kentler ve sürdürülebilir kalkınma bağlamında irdelenmesi. Social Sciences Studies Journal, 4(14), 6 Ekim 2020 tarihinde, http://www.sssjournal.com/Makaleler/1906456069_11_414_ID370.\%20Emrah\%20AKDAMAR_415-427.pdf adresinden erişildi.

Akpolat, M. D. (2010). Gaziantep kalesi kentli kale. Ankara:Özkan Matbaacllı.

Altunsoy, A. (2005). Kentsel tarihi çeore koruma (Kars üzerine bir inceleme). Yüksek Lisans Tezi. Bursa Uludağ Üniversitesi Açık Erişim Arşivi. https://acikerisim.uludag.edu.tr/simple-search?location=\%2F\&query=ali+altunsoy\&rpp=10\&sort_by=score\&order=desc

Atasoy, B. (2018). Mahalle sakinlerinin kentsel koruma alanlarındaki sağllklaştırma uygulamalarnna etkisi "Gaziantep Suyabatmaz mahallesi örneği". Yüksek Lisans Tezi. Ulusal Tez Merkezi Arşivi. https://tez.yok.gov.tr/UlusalTezMerkezi/tezSorguSonucYeni.jsp 
Ay, Y. S. (2001). Gaziantep'te planlamaya genel bakış. Türkiye Mühendislik Haberleri, 415, 44-46. 5 Ekim 2020 tarihinde, http://www.imo.org.tr/resimler/ekutuphane/pdf/380.pdf adresinden erişildi.

Basmacı, D. (2017). Kültürel mirasın korunmasında yerel yönetimlerin rolü: Beyoğlu belediyesi örneği. Aurum Mühendislik Sistemleri ve Mimarlı Dergisi, 1(2), 77-90, 3 Ekim 2020 tarihinde, https://dergipark.org.tr/tr/download/article-file/463416 adresinden erişildi.

Beyhan, Ş. G. ve Öçal, H. (2010). Cumhuriyet Dönemi Mimarlı̆̆ı, Isparta'da Modernizm Etkisindeki Konutların Mimari Kimliği Üzerine. Mimarlık Dergisi, 355, 18 Şubat 2021 tarihinde, http://www.mimarlikdergisi.com/index.cfm?sayfa=mimarlik\&DergiSayi=369\&RecID=2484 adresinden erişildi.

Bilenser, E. (2002, 25 Mayıs). Türkiye'de tarihi kent dokularının korunması ve geleceğe taşınması. Bursa Olay Gazetesi, ss. 10.

Bilgili, M. Y. (2017). Ekonomik, Ekolojik ve Sosyal Boyutlarıyla Sürdürülebilir Kalkınma. Journal of International Social Research, 10(49), 555-569. doi: 10.17719/jisr.2017.1608

Bodur, A. (2018). Risk azaltma yaklaşımı çerçevesinde dirençli kentler. İdealkent Dergisi, 28(10), 1260-1263. doi: 10.31198/idealkent.618696

Can, A. (2014). Yerel yönetimler ve kültür politikaları bağlamında İstanbul' da kentsel koruma sorunsalına sürdürülebilir çözüm önerileri. Marmara Sosyal Araştırmalar Dergisi The Journal of Marmara Social Research, 5. 5 Ekim 2020 tarihinde, http://dspace.marmara.edu.tr/handle/11424/3662 adresinden erişildi.

Can, M. G., (2010). Gaziantep kent bütünü imar planı proje yarışması. Planlama Dergisi, 50, 159-160. 4 Ekim 2020 tarihinde, http://www.spo.org.tr/resimler/ekler/0338a963b913bf2_ek.pdf adresinden erişildi.

Çelik, D., Yazgan, M.E. (2009). Kentsel peyzaj tasarımı kapsamında tarihi çevre yenileme çalışmalarının araştırılması: Beypazarı örneği. Tekirdă̆ Ziraat Fakültesi Dergisi, 6(3), 235-244. 5 Ekim 2020 tarihinde, https://dergipark.org.tr/tr/pub/jotaf/issue/19047/201446 adresinden erişildi.

Demirkaya, Y. (2008). Yerel yönetimlerde bir politika transfer aracı olarak benchmarking. "İş Güç" Endüstri Ilişkileri ve İnsan Kaynakları Dergisi, 10(1), 159-179. doi: 10.4026/1303-2860.2008.0068.x

Donald, B. (2001). Competitiveness and quality of life in city regions: Compatible concepts?. Canadian Journal of Urban Research, 10(2). 5 Ekim 2020 tarihinde, https://www.jstor.org/stable/44320670?seq=1\#metadata_info_tab_contents adresinden erişildi.

EDAM (Ekonomi ve Dış Politika Araştırmalar Merkezi). (t.y.). Türkiye için bir rekabet endeksi 2014. Erişim adresi: https://edam.org.tr/wp-content/uploads/2016/11/rekabet_web.pdf 
Ersezgin, A. (2002). Türkiye'de tarihi kentlerin korunmasında yerel yönetimlerin sorumlulukları ve yeri. Beşbaş, N., \& Sevinç, M.(Der.), Türkiye'de tarihi kent dokularının korunması ve geleceğe taşınması sempozyumu içinde (s. 61-69). Ankara: Kültür Bakanlığı KTVKGM Yayını.

Eryazıcıoğlu, M. E. (2018). Kültürel miras ve insan hakları bağlamında Türkiye'de koruma sisteminin incelenmesi: İstanbul tarihi yarımada örneği. Doktora tezi. Ulusal Tez Merkezi Arşivi. https://tez.yok.gov.tr/UlusalTezMerkezi/tezSorguSonucYeni.jsp

Egeplan (2020). Gaziantep 2040 il çevre düzeni planı açıklama raporu. 07 Ekim 2020 tarihinde https://gaziantep.bel.tr/uploads/2020/07/plani-aciklama-raporu6846.pdf adresinden erişildi.

Gürlük, S. (2010). Sürdürülebilir kalkınma gelişmekte olan ülkelerde uygulanabilir mi?. Eskişehir Osmangazi Üniversitesi İ̈BF Dergisi, 5(2). 6 Ekim 2020 tarihinde, http://www.acarindex.com/dosyalar/makale/acarindex-1423880316.pdf adresinden erişildi.

Gülhan, D. (2016). Sürdürülebilir kent ve kentsel kimlikörnekler: Birgive Bergama. Doktora Tezi. Dspace Kurumsal Arşivi. (https://dspace.ankara.edu.tr/xmlui/handle/20.500.12575/37646?show=full)

ISO 37120: (2014). Toplulukların sürdürülebilir gelişimi - Şehir hizmetleri ve yaşam kalitesi için göstergeler. 18 Şubat 2021 tarihinde https://www.iso.org/standard/62436.html adresinden erişildi.

İnan, Ö. Y. ve Sönmez, N. Ö. (2019). Kentsel yaşam kalitesi ölçüm yöntemlerinin geliştirilmesi. International Journal of Economics, Politics, Humanities \& Social Sciences, 2(3). 5 Ekim 2020 tarihinde, https://dergipark.org.tr/tr/download/articlefile/761977 adresinden erişildi.

Kabadayı, H. (2006). Yaşam kalitesi ve kullanıcı memnuniyetinin kentsel tasarımdaki etkisine çok boyutlu yaklaşım. Yüksek Lisans Tezi. Dspace Kurumsal Arşivi. http://hdl.handle.net/11527/2330

Kentsel Yaşam Kalitesi Özel İhtisas Komisyonu Raporu. (2018). 11. Kalkınma Planı (2019-2023) (Yayın No: KB: 3014- ÖİK: 795). Ankara: Türkiye. T.C. Kalkınma Bakanlığı.

Kuban, D. (2001). Türkiye'de kentsel koruma: kent tarihleri ve koruma yöntemleri. İstanbul:Türkiye Ekonomik ve Toplumsal Tarih Vakfı.

Koruma Uygulama Denetim Bürosu Şube Müdürlüğü (KUDEB). (2011). Osmanlı Dönemi Gaziantep Mahalleleri ve Bey Mahallesi, İmar ve Şehircilik Daire Başkanlığı KUDEB.

Marans, R. (2007). Kentsel yaşam kalitesinin ölçülmesi. Mimarlık Dergisi, 335. 5 Ekim 2020 tarihinde, http://www.mimarlikdergisi.com/index.cfm?sayfa=mimarlik\&DergiSayi=53\&RecID=\%201326\&1534D83A_1933715A=75925ecdebffda9e6a3e309f425216fbc3b8dc41 adresinden erişildi. 
Marans, R. W. ve Couper, M. (2000). Measuring the quality of community life: a program for longitudinal and comparative international research içinde Paper presented to the Second International Conference on Quality of Life in Cities içinde (s. 267276). Singapore.

Mazcioğlu, E. (2018). Konut ve konut çevresi seçiminde etkili parametrelerin kentsel yaşam kalitesi bağlamında incelenmesi: Gaziantep örneği. Yüksek Lisans Tezi. Dspace Kurumsal Arşivi. https://hdl.handle.net/20.500.11782/1751

Paris Deklarasyonu. (2011). On heritage as a driver of development adopted at Paris, UNESCO headquarters, on Thursday 1st December 2011. 20 Ekim 2020 tarihinde http://www.icomos.org.tr/Dosyalar/ICOMOSTR_en0294537001587380802.pdf adresinden erişildi.

Şahin, M.A. (2016). Kentsel dönüşüm uygulamalarının planlama Bütünlüğüne etkileri: Gaziantep Şahinbey ve Şehitkâmil İlçeleri örneği. Yüksek Lisans Tezi. Ulusal Tez Merkezi Arşivi. https://tez.yok.gov.tr/UlusalTezMerkezi/tezSorguSonucYeni.jsp

Tatlıgil, F. (2005). Gaziantep kentinin geleneksel konut dokusunun ve sosyo-kültürel yaptsindaki değişimin incelenmesi. Yüksek Lisans Tezi. YTÜ DSpace Kurumsal Arşivi. http://dspace.yildiz.edu.tr/xmlui/handle/1/11195

T.C. Cumhurbaşkanlığg Strateji ve Bütçe Başkanlığı. (2019). Sürdürülebilir Kalkınma Amaçları Değerlendirme Raporu. Erişim adresi:https://www.sbb.gov.tr/wp-content/uploads/2020/03/Surdurulebilir-Kalkinma-Amaclari-Degerlendirme-Raporu_13_12_2019-WEB.pdf

Tekeli, İ. (2010).Gündelik yaşam, yaşam kalitesi ve yerellik yazıları. İstanbul: Tarih Vakfı Yurt Yayınları.

Tekeli, İ. (2011). Bir kültür odağı olmanın İstanbul'un dünya kenti olmasındaki rolünü tartışmak. B. Özoğuz, M. Aşkın, S. Karcıŏlu, A. Can (Der.). İstanbul Hayal ve Gerçek içinde (s. 134-147). İstanbul: Marmara Belediyeler Birliği Yayını.

Torlak, S. ve Yavuzçehre, P. S. (2005). Belediyelerin kentsel yaşam kalitesine etkileri ve Denizli Karşıyaka mahallesi örnegi. Ş.P.O(Der.), 8 Kasım Dünya Şehircilik Günü, 29. Kolokyumu, Planlamada Yeni Politika ve Stratejiler, Riskler ve Firsatlar içinde (s. 327-337). İstanbul: T.M.M.O.B. Şehir Plancıları Odası.

Turan, İ., Şimşek, Ü. ve Aslan, H. (2015). Eğitim araştırmalarında likert ölçeği ve likert-tipi soruların kullanımı ve analizi. Sakarya Üniversitesi Eğitim Fakültesi Dergisi, 30. 13 Ekim 2020 tarihinde, https://www.researchgate.net/publication/288653889_Egitim_Arastirmalarinda_Likert_Olcegi_ve_Likert-Tipi_Sorularin_Kullanimi_ve_Analizi adresinden erişildi.

Türkiye'nin Şehirleri Sürdürülebilirlik Araştırması, (2011). 18 Şubat 2021 tarihinde https://v3.arkitera.com/UserFiles/File/download/Turkiyenin_Illeri_Surdurulebilirlik_Arastirmasi.pdf adresinden erişildi.

TÜİK (2019). Yaşam memnuniyeti araştırması mikro veri seti. Erişim tarihi: https://www.tuik.gov.tr/media/microdata/pdf/yasam-memnuniyeti-arst.pdf 
Türkoğlu, İ. (2020). Sürdürülebilir kalkınmada kültür mirasının yeri ve önemi. Trakya Üniversitesi Edebiyat Fakültesi Dergisi, 10(20), 117-143. doi: 10.33207/trkede.692194.

Türksever, A. N. (2001). Türkiye'de büyükşehir alanlarında yaşam kalitesinin değerlendirilmesine yönelik bir yöntem denemesi. Doktora tezi.Dspace Kurumsal Arşivi. http://hdl.handle.net/11527/12063

Uğur, H. (2004). Geleneksel şehirsel mekanlar, değerlendirme ve korunmaları bağlamında sistematik yaklaşım-Gaziantep örneği. Doktora tezi.DSpace Kurumsal Arşivi. https://polen.itu.edu.tr/xmlui/handle/11527/10529

UNESCO, (1972). Dünya kültürel ve doğal mirasının korunmasına dair sözleşme. https://unesco.org.tr/Pages/161/177 adresinden erişilmiştir.

UNESCO, (1989). Third Medium-Term Plan (1990-1995). https://unesdoc.unesco.org/ark:/48223/pf0000084697 adresinden erişilmiştir.

United Nations. (2004). Urban indicators guidelines: United Nations Human Settlement Programme. United Nations Publications.

URAK (Uluslararası Rekabet Araştırmaları Kurumu). (t.y.). İlerarası Rekabetçilik Endeksi 2018. http://www.urak.org/wp-content/uploads/2019/05/URAK_\%C4\%B0RE_2018-2.pdf adresinden erişildi.

Valetta İlkeleri, (2011). Tarihi Kentlerin ve Kentsel Alanların Korunması ve Yönetimiyle İlgili Valetta Illkeleri. 20 Ekim 2020 tarihinde http://www.icomos.org.tr/Dosyalar/ICOMOSTR_tr0592931001536912260.pdf adresinden erişildi.

Varol, E. (2019). Kültürel mirasın korunmasında yerel yönetimlerin rolü; tarihi Trakya Roma su isale hattı örneği. Yüksek Lisans Tezi. İstanbul Üniversitesi Tez Arşivi. http://katalog.istanbul.edu.tr/client/tr_TR/default_tr/search/detailnonmodal/ent:\$002f\$002fSD_ILS\$002f0\$002fSD_ILS:2483680/ada?qu=K\%C3\%BClt\% C3\%BCr+--+Roma\&ic=true\&ps=300)

Veenhoven, R. (2000). The four qualities of life, ordering concepts and measures of the good life. Journal of Happines Studies, 1, 1-39. doi: 10.1007/978-94-007-57028_11

Yavuzçehre, P. S. ve Torlak, S. (2006). Kentsel yaşam kalitesi ve belediyeler: Denizli Karşıyaka mahallesi örneği. Süleyman Demirel Üniversitesi Sosyal Bilimler Enstitüsü Dergisi, 2(4), 5 Ekim 2020 tarihinde, https://dergipark.org.tr/tr/pub/sbe/issue/23207/247877 adresinden erişildi.

Yenice, M. S. ve Karadayı Yenice, T., (2018). Gaziantep kenti planlama deneyimleri üzerine bir süreç değerlendirmesi. Gaziantep University Journal of Social Sciences, 17 (2), 552-562. doi: https://doi.org/10.21547/jss.374644

Yenişehirlioğlu, F. (2002). Kültür mirası, kültürel kimlik ve yerel yönetimler. Beşbaş, N., \& Sevinç, M.(Der.) Türkiye'de tarihi kent dokularının korunması ve geleceğe taşınması sempozyumu içinde (s. 69-76). Ankara: Kültür Bakanlığı KTVKGM Yayini. 
Yıldırım, A. E. (2017). Habitat III'ün ardından. Mimarlık Dergisi, 393.5 Ekim 2020 tarihinde http://www.mimarlikdergisi.com/index.cfm?sayfa=mimarlik\&DergiSayi $=407 \&$ RecID $=4098$ adresinden erişildi.

Yıldız Özlü, Z. (2017). Gaziantep'in 1923-1938 yılları arasında ekonomik ve bayındırlık alanındaki faaliyetleri. Uluslararası Sosyal Araştırmalar Dergisi, 10 (51), 330342. doi:http://dx.doi.org/10.17719/jisr.2017.1769 